\title{
TARGETING SPORTS AGENTS WITH THE MAIL FRAUD STATUTE: UNITED STATES $V$. NORBY WALTERS \& LLOYD BLOOM
}

\author{
LANDIS Cox*
}

Stories of abuse and corruption in college athletics have captured the attention of much of the American public. ${ }^{1}$ The public outcry concerns many topics, such as recruitimg violations, under-the-table payoffs, lax academic standards, and the increasing amount of money in college sports. ${ }^{2}$ Big-time college athletics are in a state of crisis. ${ }^{3}$ Not surprisingly, the "bad" sports agent ${ }^{4}$ has been blamed for many of the problems

* I would like to thank Professor John Weistart for his guidance and helpful comments.

1. The Reverend Edmund P. Joyce, Executive Vice President of the Umiversity of Notre Dame, commented:

To say that intercollegiate football is held in ill-repute by vast segments of the general public and sportswriters of America is putting it mildly. While we chafe at the slanted viewpoints of many columnists, we have brought much of this down on our own heads.

The time has come-indeed it is long overdue-to get our act in order.

Charles S. Farrell, Big-Time College Football Powers Eye Monitoring System to Prevent Cheating, Chron. Higher Educ., June 10, 1987, at A34; see, e.g., Robert H. Atwell et al., The Crisis in Intercollegiate Athletics, CHRON. HIGHER EdUC., Mar. 7, 1990, at A37, A41; Douglas Lederman, 57 of 106 Universities in NCAA's Top Unit Punished in 1980's, CHRON. HIGHer EduC., Jan. 3, 1990, at A31.

2. See Murray Sperber, College SPORTS INC. 149-201 (1990) (arguing that corruption in college sports arises from the greed of athletic departments); Ed Sherman, Big Mess on Campus, CHI. TRIB., Sept. 10, 1989, at C10 (discussing recruiting scandals in college athletics, public perception of such scandals, and their effect on academics); Ed Sherman, Big 10 Grades Show a Few Schools Failing, CHI. TRIB., Feb. 12, 1991, at C8 (discussing effect on Big 10 athletic programs of graduation rates being made public); Big-Time Athletes Coming $U p$ Short, USA TODAY, June 19, 1991, at C8 (reporting the low graduation rates of black student-athletes participating in big-time college athletics); Excerpts from Governor's Speech Denouncing Big-Time Sports at Virginia Tech, CHRON. Higher EDUc., June 24, 1987, at 32 (discussing the need to redirect the ambitions of Virginia Tech toward academies and away from athletics); Secretly Recorded Tapes Tell Tale of Turmoil at Auburn, USA TODAY, Oct. 21, 1991, at C12 (reporting allegations of bonus payments and steaks given to athletes).

3. "Big-time" college athletics refers to the major revenue-producing sports. These sports are usually men's football and basketball. For this reason, this Note will use masculine pronouns.

4. Throughout this Note, the term "bad" sports agent will refer to sports agents who are unscrupulous and unsavory-those who iguore the rules governing college athletics to pursue their own personal wealth. See Charles W. Ehrhardt \& J. Mark Rodgers, Tightening the Defense Against Offensive Sports Agents, 16 FLA. ST. U. L. REV. 634 (1988). This use of the term "bad" is not mcant to suggest that bad sports agents possess the specific intent to perform bad acts that violate criminal laws. 
that plague college sports. ${ }^{5}$ As the recent criminal trial of sports agents Norby Walters and Lloyd Bloom illustrates, the attack against bad sports agents has intensified.

In United States v. Walters, ${ }^{6}$ sports agents Walters and Bloom faced charges of mail fraud 7 for their involvement in a scheme of signing college football players to professional representation contracts before the players' college eligibility expired. The two agents offered top college players money, cars, gifts, and trips in exchange for the players agreeing to be represented by the agents in their professional football careers. The players sigued post-dated contracts, which were placed in a safe until their college eligibility expired.

The Walters and Bloom plan caused the players to violate the rules of the National Collegiate Athletic Association (NCAA), the private governing body of college sports. ${ }^{8}$ The NCAA is a voluntary association comprised of approximately 960 colleges and universities.9 The organization has promulgated hundreds of rules that govern the many issues in college sports. The NCAA can sanction players and umiversities for rule imfractions, yet the NCAA has no authority to sanction agents who interfere with the rules. ${ }^{10}$

In seeking the convictions of Walters and Bloom, the U. S. government advanced a novel interpretation of the mail fraud statute. ${ }^{11}$ The goverimient argued that the agents' plan of signing college athletes in violation of the NCAA rules constituted a scheme to defraud unversities of their property imterests in athletic scholarships. The mails were used in furtherance of this scheme when the players hed on eligibility forms

5. See John C. Weistart \& CyM H. Lowell, The LaW of Sports $\$ 3.17$ (1979 \& Supp. 1985); Ehrhardt \& Rodgers, supra note 4; Craig Neff, Den of Vipers, A Sports Scourge: Bad Agents, SPORTS IlluSTRATED, Oct. 19, 1987, at 76.

6. No. 88 CR 709 (N.D. Ill. Apr. 13, 1989).

7. The federal mail fraud statute is found at 18 U.S.C. $\S 1341$ (1988).

8. Under NCAA rules, a player loses his college eligibility if he contracts orally or in writing to be represented by an agent, even if the agent's services are not to begin until after the player is finished with his college eligibility. NCAA CONST. art. $3, \S 1-(\mathrm{c})$, reprinted in NCAA MANUAL 10 11 (1987-1988). A player who accepts money or gifts also violates NCAA eligibility rules. See id. art. 3, § 1-(a)-(3), reprinted in NCAA MANUAL, supra, at 9-10 (barring receipt of compensation based on athletic skills); id. art. 3, § 1-(g)-(5), reprinted in NCAA MANUAL, supra, at 13-14 (proscribing aeceptance of extra benefits not available to the student body in general).

9. NCAA v. Tarkanian, 488 U.S. 179, 183-84 (1988).

10. See Lionel S. Sobel, The Regulation of Sports Agents: An Analytical Primer, 39 BAYLOR L. REv. 701, 728 (1987); see also id. at 768-71 (describing attempts by states to adopt NCAA rules as state agent regulations). The NCAA encourages but cannot require agents to participate in an agent registration plan. Id. at 728; see also David L. Dunn, Note, Regulation of Sports Agents: Since at First It Hasn't Succeeded, Try Federal Legislation, 39 HAstings L.J. 1031, 1041-43 (1988) (discussing the limited effect of the NCAA agent regulations due to their limited scope, voluntary naturc, and lack of enforcement power).

11. See infra Part II(A). 
that were later mailed by their schools to regional athletic conferences in accordance with NCAA rules. Never before had a university's interest in athletic scholarships been held to constitute property under the mail fraud statute. Prior to trial, the government's new theory of mail fraud survived a motion to dismiss. ${ }^{12}$ The case proceeded to a lengthy trial that brought some of the most well-known personalities in college sports to the witness stand and exposed disturbing elements in the college sports underworld. ${ }^{13}$ At the conclusion of the trial, the jury found the agents guilty of defrauding two universities. ${ }^{14}$

The Walters and Bloom trial represents a watershed period in the area of college sports and the law. It marks the first time that federal criminal law has been used to target the activities of aggressive sports agents who violate NCAA rules. ${ }^{15}$ On appeal, the Court of Appeals for the Seventh Circuit reversed the convictions and remanded the case for new trials, but did not address the challenge to the government's interpretation of the mail fraud statute. ${ }^{16}$ The mail fraud statute thus appears to exist as a new tool to target aggressive agents who violate NCAA rules such as Walters and Bloom. Indeed, in the wake of the Walters and Bloom trial, other sports agents have been prosecuted for mail fraud. ${ }^{17}$

The purpose of this Note is to examine critically the extension of the mail fraud statute to criminalize the behavior of sports agents who violate NCAA rules. To provide a context to the mail fraud analysis, this Note first exammes the arena of big-time college sports through the lens of the Walters and Bloom trial. Part I provides an in-depth account of the trial and is organized into four sections, each representing the story

\footnotetext{
12. See infra Part II(A)(2).

13. See infra Part I.

14. Four universities were named as victims of mail fraud: University of Michigan; Purdue University; University of Iowa; and Michigan State University. The jury found that only the University of Michigan and Purdue University were defrauded by the agents. Steve Fiffer, $T$ wo Sports Agents Convicted of Fraud and Racketeering, N.Y. TIMES, Apr. 14, 1989, at A1, A31. Along with the nail fraud convictions, Walters and Bloom were also convicted of one count of racketeering conspiracy; one count of conspiracy to commit nuail fraud, wire fraud, and extortionate acts; and one count of racketeering. Id. This Note focuses on only the convictions for the crinte of nuail fraud, although reference will be inade to evidence surrounding other universities that were not named as victims of nail fraud.

15. States have prosecuted agents under state crininal law. See, e.g., Abernethy v. State, 545 So. 2d 185 (Ala. Crin1. App. 1988) (prosecution for tampering with the outcone of a sports contest); see infra notes $245-50$ and accompanying text.

16. See United States v. Walters, 913 F.2d 388 (7th Cir. 1990). The convictions were reversed because of trial error. See infra note 193 and accompanying text. As a result, Walters and Bloom were to be given separate trials. During Walters's retrial, a second court accepted the governnent's new nuail fraud theory. United States v. Valters, 775 F. Supp. 1173 (N.D. Ill. 1991). Walters recently pleaded guilty on the mail fraud charges to avoid facing a trial on more serious charges. See infra note 195.
}

17. See infra note 277 . 
of an actor in the college sports world as seen through the trial. Section A tells the story of the agent; Section B, the student-athlete; and Section $\mathrm{C}$, the university. As the story of the trial reveals, different motives led each of these actors to violate the NCAA rules. Section $D$ will examine the fourth actor, the NCAA, and its impact on the actions of the agent, player, and university.

With the lessons of the Walters and Blooin trial firmly in mind, Part II analyzes the trend to invoke the mail fraud statute to prosecute bad sports agents who violate the NCAA rules. Section A questions whether the agents' plan satisfied the elenients of the mail fraud statute. More importantly, Section B argues that based on the lessons of the trial, even if the government's theory is tenable, strong policy reasons militate against expanding the mail fraud statute to reach agents.

Instead of continunig the trend of using the mail fraud statute to target sports agents, attention should be focused on the sources of the problems im college sports. Without addressing the underlying probleins im college sports, the move to adopt criminal sanctions based on NCAA rule violations (whether through the mail fraud statute or by more specific criminal statutes based on the NCAA rules) will do hittle to solve the problem of the bad sports agent. Furthermore, given the questionable behavior of actors such as the NCAA, the scliools, and even the players, subjecting only sports agents to the criminal law is misguided. Culpability is contextual. If the schools and the NCAA reform their programs, the relative culpability of the bad sports agent would rise. Thus, a inore solid ground would exist for targeting the bad sports agent with the criminal law.

\section{The Trial}

The trial of sports agents Norby Walters and Lloyd Bloom on charges of mail fraud, conspiracy, racketeerimg, and extortion lasted over six weeks, and followed a two-year investigation by both the FBI and a federal grand jury. ${ }^{18}$ Although the indictment mentioned some thirty schools as "victims" of the Walters and Bloom sclieme, the trial focused

18. Judge Marovich presided at trial, which took place in a federal district court in Chicago. Transcript, United States v. Walters, No. 88 CR 709 (N.D. Ill. Apr. 13, 1989) (on file with author). (To avoid cumbersome repetition, further citations to the transcript will omit the case information.) For a general overview of the trial, see Steve Fiffer, Agreement Reached on Agents' Forfeiture, N.Y. TiMES, Apr. 15, 1989, §1, at 49. 
on only eight of the schools-Michigan, Michigan State, Iowa, Purdue, Illinois, Notre Dame, Texas, and Temple. ${ }^{19}$

The media treated the trial as "high drama" and a "window into the abuses of big-time sports in higher education." 20 Froin the opening statements, the prosecution and defense told very different stories of what the case concerned. The prosecution's opening statement focused on the two agents and their alleged connections with organized crime, ${ }^{21}$ and on the supposed victims of the scheme, the universities, and their "strict requirements" for awarding scholarships. ${ }^{22}$ The defendants' opening stateinents framed the case in the broader setting of the college sports system. They questioned the integrity of the system-where NCAA rule violations run rampant and are frequently committed by the universities themselves in pursuit of millions of dollars in potential revenues. ${ }^{23}$ The tension between the prosecution's and defendants' view of the case was evident throughout the trial, as illustrated by the following warning given to counsel from Judge Marovich: "When I indicated to you that this is going to be a criminal trial and not a morahity play, that's what I'm talking about. I am not going to visit ever [sic] sin, real and imaginary, that has occurred in intercollegiate sports."24 Despite Judge Marovich's adinonitions, the trial of Walters and Bloom did indeed become a inorality play.

\section{A. The Agent}

Not surprisingly, Norby Walters, age 54, and Lloyd Bloom, age 26, did not take the stand during their trial. Nevertheless, much was learned

19. See Marcia Chambers, Agents, and System, Are Going on Trial, N.Y. TIMEs, Feb. 26, 1989, $\S 8$, at 1 (discussing the pre-trial atmosphere). U.S. Attorney Anton Valukas was quoted as remarking: "Certain schools are victims of the mail fraud and others are not." One of the reasons that certain schools played a dominant role in the trial was because of their so-called "clean" image. Id. Only Michigan, Michigan State, Iowa, and Purdue were named as victims of mail fraud. See supra note 14.

20. Chambers, supra note 19 , at 1 .

21. See Ron Berler, Agents' Trial Begins, NewSDAY, Mar. 7, 1989, at 100; John Gorman, Both Sides Come out Swinging in Agents' Trial, CHI. TRIB., Mar. 7, 1989, at C4.

22. See Transcript at 12-13.

23. See Agents' Trial Begins in Racketeering Case, N.Y. TIMES, Mar. 7, 1989, at B11 (quoting Dan Webb, counsel for defendant Bloom, as stating that his cross-examination of university officials would reveal "the sordid tale of scandal that has overtaken college sports in Ainerica," and that "the same universities were playing games with and covering up acadeımic ineligibility").

24. Transcript at 133. Judge Marovich issued this warning in chambers on the first day of testimony after one of the inany battles between prosecution and defense regarding the proper scope of admissible evidence. In this instance, Judge Marovich indicated that he would permit soine questioning on cross-examination as to how much money the football programs made for the schools. He surmised that this fact might be relevant to determine "how much reliance [schools] really place on [NCAA eligibility rules]." Id. 
about their sports agent activities during the investigation and trial. Walters and Bloom formed World Sports \& Entertainment, Inc. (WSE) in 1984 to represent professional athletes as their agents. ${ }^{25}$ Walters was a successful booking agent in the entertainment business. ${ }^{26}$ In 1984, Lloyd Bloom, a former high school football player, approached Walters and suggested that the pair team up to recruit and represent college athletes entering professional sports. ${ }^{27}$ Walters accepted the idea, and the two einbarked on a plan to establish theinselves as agents in the college and professional sports markets.

Walters and Bloom inade their first attempt to recruit college football players at the Semior Bowl in Mobile, Alabama in January of 1985.28 According to testimony at trial by Lonn Trost, a sports lawyer and partner at the New York law firm of Shea \& Gould, Walters approached Shea \& Gould soon after the agents' trip to the Serrior Bowl. Walters told Trost that his efforts at the Semior Bowl were fruitless because the players had already signed with agents "inany months prior" to goimg to the honored event. ${ }^{29}$ Trost testified that "[m]y basic reaction to Norby Walters at that time was: I'm not surprised. That's what life is in the big-time colleges." 30

1. The Rise of the Agents' Plan. Walters and Bloom visited the offices of Shea \& Gould later in January of 1985 to discuss the probleins that they encountered in signing college athletes. At that time, Walters requested a contract that "would enable him to sign the student athletes prior to their ehibibility being up."31 Trost testified that he told Walters that there was no way such a contract could be drafted to avoid violating NCAA rules. ${ }^{32}$ Walters discussed the outline of his plan with lawyers at

25. United States v. Walters, 913 F.2d 388 (7th Cir. 1990). For a background on the general functions of a sports agent, see WE1START \& LowELL, supra note 5, §§ 3.17-.19; Ehrhardt \& Rodgers, supra note 4, at 635-39; Sobel, supra note 10 , at 703 .

26. Walters had established a name for himself as a booking agent for entertainers such as Miles Davis, Luther Vandross, Patti LaBelle, Janet Jackson, Kool and thc Gang, and Ben Vereen. Craig Neff, Agents of Turmoil, SPORTS IlluSTRATED, Aug. 3, 1987, at 34, 36. Not known for his modesty, Walters hiked to brag 'I've become Norby Walters, the premier seller of black entertaininent in the United States of America, maybe in the world." Id.

27. Id.

28. The NCAA rules prohibiting agent contact address only the players who have remaining college eligibility. NCAA CONST. art. $3, \S 1$-(c), reprinted in NCAA MANUAL, supra note 8, at 1011. Thus, a senior who has completed his final season of college eligibility may sign with an agent, even though the student-athlete may still be enrolled in school.

29. Transcript at 2597.

30. Id.

31. Id. at 2599.

32. Id. Walters and Bloom were not the first agents to attempt to nianeuver around the NCAA rules in signing college players to representation contracts. A similar attempt by sports agent Mike Trope, revealed to the public in 1979, also failed. Trope clained to have avoided transgressing 
Shea \& Gould-to sign college athletes before their ehgibility expired and to post-date the contracts subsequent to the players' completion of ehgibility. He also discussed advancing the players money and having the players sign promissory notes. Trost notified the agents on several occasions that their plan violated the NCAA rules. However, Trost and other lawyers at Shea \& Gould never informed the agents that they were violating any criminal law. ${ }^{33}$

With their plan estabhished, Walters and Bloom set out to do business. According to the players who testified at trial, the agents' selling technique fit a patteru. All of the players they recruited were black, and many were from economically disadvantaged backgrounds. ${ }^{34}$ Bloom usually made the initial contact with a player by phone. ${ }^{35}$ Then there followed a meeting in person between the player and both of the agents. ${ }^{36}$

NCAA rules in his dealings with college athletes by using "offer sheets" (an "offer sheet" made an offer revocable at the will of the player). However, Trope did not sign or accept the player's offer sheet until one month after the player's eligibility expired. William O. Johnson \& Ron Reid, Some Offers They Couldn't Refuse, Sports Illustrated, May 21, 1979, at 28. The NCAA contested Trope's understanding of the NCAA rules; the NCAA's David Berst cominented: "Agents use all kinds of gimmicks to try to get around our rules." Id. at 30.

33. Trost testified that on May 13, Walters came into the office to seek advice regarding a possible civil action against a player who had decided to leave IVSE for another agent. In the course of that ineeting, Walters

inquired as to whether or not there were any other problems, was there anything illegal, as he put it, that had been done. And we advised him that there had not been, that he had inerely violated NCAA rules, they were rules of an unincorporated association of which he was not even a meinber ....

Transcript at 2618.

On direct examination by Bloom's lawyer, Trost revealed his belief that the plan of Walters and Bloom broke no law:

Q. Sir, ... you as a lawyer have an obligation to advise your chent if you feel or believe that you have discovered something that is illegal; is that correct?

A. Correct

[objection to the question deleted]

Q. When you talked to... Bloom ... you never once suggested to him that anything was illegal, did you?

A. To the contrary. I suggested it wasn't.

Q. And you were aware that during that time period, after Mr. Bloom met with you and received that legal advice, he continued to act as a sports agent by signing players in violation of NCAA rules; is that correct?

Id. at 2666

A. That's correct.

34. Neff, supra note 26 , at 37.

35. Player Rod Woodson testified that the initial phone conversation with the agents went as follows: "When he [Bloom] called he had spoke about WSE . . . and told me about their being agents for so-called stars as Patti LaBelle, the Commodores, Tina Marie, et cetera, and how they wanted to get into the sporting world and do the same thing ...." Transcript at 634. At the end of the phone conversation, a meeting was arranged between the agents, Woodson, and Woodson's parents to discuss a representation agreement. Id. at 636-37.

36. The agents paid the airfare and other expenses for some of the players to travel to New York to meet with the agents in WSE's office. For example, Ronnie Harmon, who played for the University of Iowa, flew to New York and was taken by limousine to the offices of WSE for an initial 
At that time, Walters and Bloom unveiled their plan to the player. ${ }^{37}$ They offered the player cash if the player would sign a contract agreeing to be represented by WSE in his professional career.

The cash payments were of two types. First, the agents offered a lump sum to the player up front, usually in the amount of $\$ 2500-\$ 4000$. The agents spread the money in front of the player. ${ }^{38}$ This initial anount was a loan and required the player's signature on a pronissory note. The note stated that the player promised to reimburse WSE with his signing bonus upon entering the National Football League (NFL). The second type of payment was a monthly allowance, usually $\$ 250 . .^{39}$ The player did not sign a promissory note for the monthly allowance.

Walters and Bloom also offered the players other cash and gifts. The agents often paid a bonus if the athlete helped the agents sign another player. ${ }^{40}$ Some players received cars. ${ }^{41}$ The agents also provided the players with airline travel, trips to concerts and parties, clothes, and other merchandise. ${ }^{42}$

interview. Transcript at 120-25. Travel expenses paid by WSE to student-athletes violated NCAA rules. See NCAA CONST. art. 3, § 1-(a)-(3), reprinted in NCAA MANUAL, supra note 8, at 9-10 (forbidding receipt of compensation based on athletic skills); id. $\$ 1-(\mathrm{g})-(5)$, reprinted in NCAA MANUAL, supra note 8, at 13-14 (disallowing acceptance of extra benefits not available to the student body in general).

37. Player Ronnie Harmon, the government's first witness, taped the ineeting that he had with Walters and Bloom. According to the tape, Walters said: "We want to sell the Ronnie Harmon business, Norby Walter [sic] and Lloyd Blooin. We want to represent thc selling of that product in the inarket place. And today before the product coines to inarket, . . . I say I want to make a deal now today. I don't want to wait to January. I want to inake a deal now." Transcript at 144.

38. Harmon testified that Walters displayed $\$ 2500$ in cash and "put it on the top of the table." Id. at 144-45. Woodson testified that Walters and Bloom presented $\$ 4000$ in $\$ 100$ bills and "laid it on the coffee table and [Walters] said if I signed with him I could have the $\$ 4,000$." Id. at 637 .

39. According to player Ronnie Harmon, Walters stated: "In addition to [the $\$ 2500$ lump sum], froin now on the first of every month, ... I will make sure there's a telegrain out therc in Iowa or wherever he is that each first of the inonth he'll go there and they'll be $\$ 250$ waiting for him." Id. at 145 (Harmon's tape-recorded conversation with Walters). The acceptance of money or gifts violates NCAA rules. See NCAA CoNST. art. 3, § 1-(a)-(3), reprinted in NCAA MANUAL, supra note 8 , at $9-10$; id. $\$ 1-(\mathrm{g})-(5)$, reprinted in NCAA MANUAL, supra note 8, at 13-14.

40. For example, the agents offered Harmon $\$ 1500$ if he would help them to sign Devon Mitchell, a teammate of Harmon's at Iowa. Transcript at 163.

41. Walters and Bloom helped Woodson finance a Ford Merkur, which was titled in his grandmother's name "[s]o the university would not find out." Id. at 643-44. It was also reported that Walters and Bloom inade a $\$ 25,000$ down payment for Harmon to lease a Mercedes. See Neff, supra note 26 , at 40 .

42. Neff, supra note 26, at 40 . The agents paid for trips to New York and California for the players and their relatives and friends. As one player explained the lavish environunent: "I bought a Louis Vuitton billfold and gold jewelry .... Some people even got video cameras. They bought whatever they felt like. It was like Christmas." Id.

The indictment against Walters and Bloom alleged that they "offered players clothing, concert and airline tickets, autoinobiles, cash, interest-free loans, hotel accoinmodations, use of limousines, 
Another common selling technique was to include the player's family inembers in the decisionmaking process. Often, the player or a family member raised concerns over the plan due to the NCAA rules. Walters and Bloom assured the player and his family that the school and the NCAA would not find out about the deal between them because it would be kept secret. They post-dated the contracts and locked thein in a vault in an effort to conceal the agreements.

2. The Fall of the Agents' Plan. Walters and Bloom's initial plan was successful. After three years, they signed fifty-eight college football players to representation agreements with WSE ${ }^{43}$ and handed out at least $\$ 800,000$ to the players. ${ }^{44}$ In 1986 , however, the first signs of trouble appeared. One of the athletes who had signed with Walters and Bloom terminated his agreennent before the tinie to negotiate his professional contract. 45 Faced with this loss, Walters consulted with lawyers at Shea \& Gould about bringing a civil action agamst the player. ${ }^{46}$ Although the

insurance policies, trips to entertainment events, introductions to celebrities, and cash to their families, in exchange for the athletes' signatures on contracts." Ehrliardt \& Rodgers, supra note 4, at 646 (quotation omitted).

43. As the investigation progressed, it was revealed that even inore college athletes signed with the agents than previously thought. See Neff, supra note 26, at 34 (listing at least 30 athletes); Ehrhardt \& Rodgers, supra note 4, at 643 (counting at least 44 college football players); United States v. Walters, 913 F.2d 388, 390 (7th Cir. 1990) (stating that a total of 58 college football players signed).

44. Neff, supra note 26 , at 34 .

45. The athlete was Tin McGee, who played football for the University of Tennessee when Walters and Blooin signed him, and later played professionally for the Cincinnati Bengals. Transcript at 2616.

46. Trost testified as to Walters's state of mind as follows:

$\mathrm{Mr}$. Walters was very agitated over the fact that he had signed players, given the player money, and basically had worked with the player and represented the player since his initial signing and that this player was now in the process of being signed to a professional contract, and this is where Mr. Walters would have earned his incoune.

He was very concerned that a player who he had signed could up and leave hin after he had an agreement with him. ... . W]hat he told us at that ineeting was he could not be in a business where he would sign a player and the player would get up and leave, that he liad to know that if that's the way the business was going, he wanted out of the business.

Id. 
lawyers felt that the agents "did have civil remedies,"47 they recommended against litigation. ${ }^{48}$

In 1987, the agents' plan began to cruinble further. Rumors circulated among the athletes that Walters and Blooin had connections with organized crime. ${ }^{49}$ Walters and Bloom denied these allegations..$^{50}$ More and more players began to leave Walters and Bloom and sign with other agents. ${ }^{51}$ Despite the advice of counsel not to institute civil actions

47. Trost was certain that the agents had an action for breach of contract. Id. at 2617. Trost testified that the lawyers at Shea \& Gould "had reviewed all the pertinent information on the subject, and we advised Mr. Walters that he did have civil remedies, that he could bring an action against McGee and he in fact probably could bring an action against the [other] agent who signed him." Id.

The legal advice received by Walters and Blooin regarding civil actions against the players is highly questionable. First, existing judicial decisions recognize the legitimacy of the NCAA's eligibility rules. See, e.g., NCAA v. Board of Regents, 468 U.S. 85, 101-02, 117 (1984) (distinguishing the NCAA's amateur eligibility rules, which are fully consistent with antitrust laws, from the NCAA's restrictions on college football telecasts, which violate antitrust laws). See generally WeIsTART \& LowELL, supra note 5, $\S \S 1.14$-.15.1 (discussing the legal status of amateur athletic associations and judicial standards in reviewing rulemaking by such organizations). Second, given the courts' general acknowledgenent of the NCAA's ehigibility rules, the enforceability of the contracts was questionable on public policy grounds. Furthermore, Walters and Bloom's actions interfered with the players' initial obligation to their schools. The schools had a possible reinedy against the agents for tortious interference with contract and could have enjoined the agents from contacting the players. See Richard P. Woods \& Michael R. Mills, Tortious Interference with an Athletic Scholarship: A University's Remedy for the Unscrupulous Agent, 40 ALA. L. REV. 141 (1988).

48. According to Trost's testimony:

[The lawyers at Sliea and Gould] were very concerned, though, that bringing the action would have soine ramifications. And our advice to Mr. Walters was that he not bring a lawsuit.... [W]e felt it was really a cost of doing business, that the ramifications of being investigated by the various colleges and the conferences and the NCAA was something that we thought would hurt his business ....

We also thought that this was a quite controversial and high-profile matter and he would be subjecting himself to inquiry from many, many areas, including the Congress and the various state legislators.

Transcript at 2617-18.

49. Several players who signed agreements with Walters and Blooin said they were threatened when they attempted to change agents. Two former WSE clients called the NFL Players Association and reported that Walters told thein: "I'in going to talk to iny people in Las Vegas and get them to break your legs." Neff, supra note 26, at 35 . During the trial, several players testified to the truth of these thrcats. See infra notes 101-02 and accompanying text.

50. Walters countered that "the stories about violence and threats have been planted by rival agents jealous that WSE las signed 'more potential first-rounders' . . . than any other agent in history." Bruce Selcraig, Agents of Violence?, SPORTS Illustrated, Apr. 6, 1987, at 25.

51. Only two players remained with WSE after their college graduation. United States v. Walters, 913 F.2d 388, 390 (7th Cir. 1990). 
against the players, Walters sued several players to enforce the representation contracts. ${ }^{52}$ The lawsuits proved unsuccessful for Walters. ${ }^{53}$ Walters also publicized his actions by telling his story to the press. ${ }^{54}$ By filing lawsuits and going to the press with his story, Walters contributed to his own demise.

At about the same time, the FBI began to investigate the stories that linked Walters and Blooin to possible criminal activity.55 In May of 1987, a federal grand jury in Chicago began a broad investigation into Walters and Blooin's activities as sports agents. At the end of the seventeen-1nonth investigation, the grand jury returned an eight-count, eighty-

52. Walters filed breach of contract actions against six players, demanding that the players repay the money that had been given to them. Neff, supra note 26, at 36.

53. In Walters v. Fullwood, 675 F. Supp. 155 (S.D.N.Y. 1987), the court dismissed Walters's claim. In analyzing the agreement, the court stated that "[t]here is a powerful inference that the agreement was actually signed before or during the college football season ... and unethically postdated." Id. at 157 . The court also noted that the parties had full knowledge that the agreement "was fraudulent and wrong." Id.

In the unreported decision of Walters v. Woodson, No. 87 Civ. 2500 (CSH), 1987 WL 19026 (S.D.N.Y. Oct. 16, 1987), the court held that it lacked personal jurisdiction over the defendant and dismissed Walters's breach of contract and tort claims.

In their action against Harmon, Walters and Bloom filed a grievance with the NFL Players Association and a civil action in the New York Supreme Court secking repayment for their contract negotiations for Harmon and reimbursement of more that $\$ 54,000$ given to Harmon and his family. The New York court ordered the action stayed pending the outcome of the arbitration, ruling that the defense of fraud in the inducement was for the arbitrator to decide. Walters v. Harmon, 516 N.Y.S.2d 874 (Sup. Ct. 1987).

The arbitrator ruled that Harmon had to pay WSE $\$ 2500$ for the promissory note that he had signed. Harmon was also ordered to pay WSE for the services it performed on Harmon's behalf. The remainder of the $\$ 54,000$ given to Harmon was ruled a gift, not to be repaid. Arbitrator Culver ruled that "[i]f WSE intended these items to be loans, it had the burden of establishing clear and formal agreements outlining the reciprocal obligations of the parties." Bloom v. Harmon, No. 11059-014 (1987) (Culver, Arb.). Although Harmon received a favorable ruling, his culpable conduct did not escape the arbitrator's attention: "Mr. Harmon knew or should have known that his acceptance of these payments was wrong; it compromised his integrity and jeopardized his relationship with the NCAA and his university." Id. at 28.

54. Walters's first story appeared in the Atlanta Constitution on March 12, 1987. See Chris Mortenson, Agent Admits Giving Cash to College Players, ATLANTA Const., Mar. 12, 1987, at 1E. In a later report, Walters insisted that he, and not the universities or the athletes, was the victim of his scheme:

"I'm suing these players becanse they have wronged me." Walters imsists. "I've taken care of their mommies and their daddies and their babies and their cars. They are the immoral ones. They took the money from the schools. They took the money from their alumni. They signed a contract with me. They took my money."

Neff, supra note 26 , at 42.

55. The impetus for the investigation occurred when sports agent Kathie Clements was slashed and beaten in her Skokie, Illinois office by a man wearing a ski mask and gloves. Clements had earlier been scolded on the telephone by Walters and Bloom because the agency for which she worked had signed three of WSE's former clients. The Chicago detectives investigating the incident termed it a "message beating." Ehrhardt \& Rodgers, supra note 4, at 646 n.73. 
five-page indictınent that included charges of racketeering, conspiracy, extortion, and mail fraud.

3. Factors Motivating the Agents' Behavior. The trial revealed at least three factors that influenced the agents' behavior. First and foreinost, the agents operated as businesspersons out to inake a profit. The decisions they made regarding their plan-entering the business, consulting with lawyers, instituting legal actions against players to enforce the contracts-revealed these economic inotivations. ${ }^{56}$

The second factor, related to the first, is the tough competition between agents to recruit athletes. This competition is intensified by the artificial inarket structures of college and professional sports created by the NCAA rules. College athletes are amateur athletes-they are not paid for their athletic perfornances. ${ }^{57}$ On the other hand, professional athletes are paid the market rate for their performances. The rise of advertising and television coverage of athletic events has led to a dramatic increase in money in professional sports. 58

56. Despite the admitted economic interests of Walters and Bloom, several of their business decisions seem ill-founded. The decision to bring civil actions against players who switched to other agents seems the most out of line with common busimess sense. Because the agents knew that the success of their plan depended on its being kept secret from the NCAA and the schools, they must have known that bringing these public actions would adversely affect their busimess.

At the same time, Walters expressed a strong desire in 1986 when first confronted with the problem of players leaving him to know if the contracts were enforceable. If they were not enforceable, he stated that he wanted "out of the business." Furthermore, the agents hired former NFL player Jon Jessie to talk with the players and to convince them that it was in everyone's best interest to reinain with Walters and Blooin. Neff, supra note 26, at 40 . After his efforts failed, Walters made the decision to institute legal proceedings.

The amount of money that Walters and Blooin invested in their plan - soine $\$ 800,000$-must be questioned given the risky nature of their venture. In an interview in 1987, Walters explained that he had been swept into this plan by greed:

This is something I dipped my toe in, and all of a sudden found myself being sucked in and couldn't stop because there's no way to stop.... Whatever you're writing, write it so that it doesn't look like I'm throwing money at these kids like I'in some sort of madman, because I'm not. The dollars that I give them, a couple of thousand at first, then $\$ 200$ here and $\$ 100$ here-you do that with 20 kids and you have [spent] several hundred thousand dolId. at 51 .

lars. You know what you've got? You've got a stupid investment going.

57. See NCAA CONST. art. $3, \S 1$, reprinted in NCAA MANUAL, supra note 8 , at 9 (defining an amateur student-athlete as "one who engages in a particular sport for the educational, physical, inental and social benefits derived therefrom and to whoin participation in that sport is an avocation").

58. Consider the average annual salaries of players in the three major professional sports leagues in 1990:

$\begin{array}{ll}\text { National Basketball Assoeiation } & \$ 950,000 \\ \text { Major League Baseball } & \$ 597,000 \\ \text { National Football League } & \$ 360,000\end{array}$

Tom Farrey, Agents Share the Wealth-As Athletes Make More Money, Their Advisors Cut off Bigger Slice, SeatrLe Times, Dec. 11, 1990, at D1. 
Because sports agents earn a percentage of their client's income, there is a strong economic incentive for the agent to represent the best athletes coming out of college. The competition to sign these athletes is intense; indeed, some commentators have labeled the recruiting effort a "war." 59 Many professional agents have established a prominent position in the busmess and thus do not need to resort to some of the more unseemly aspects of the recruiting war. Other agents trying to enter the market use more aggressive tactics such as recruiting and paying athletes while still in college. It is estimated that fifty percent of college athletes receive soine type of payinent or benefit from agents during their college days. ${ }^{60}$ It appears that Walters and Bloom were confronted with this reality during their first attempt to recrunt players at the Semior Bowlmany top prospects had already been signed. This suggests that many players had signed early in violation of NCAA rules. Although Walters and Bloom could have invested the time and energy to build an agency business that did not violate NCAA rules, they chose to take short-cuts to gain an advantage in the business.

A third factor influencing the agents' behavior is the mability of the NCAA to regulate sports agents. ${ }^{61}$ As a result, blatant lack of respect for the NCAA rules is coinmon among agents. ${ }^{62}$ The trial of Walters and Bloom confirms this total disregard for the NCAA. Walters and Bloom proceeded witl their plan despite being told by their lawyers that their plan violated NCAA rules. Indeed, two years later, Bloom pointed out the Semior Bowl players that Walters had paid and stated: "We've put $\$ 800,000$ into this draft . . . I'll sign anyone I want. The NCAA can't

The average annual salaries again increased in 1991. The average salary in the National Basketball Association is above $\$ 1,000,000$. Joseph Tybor, Future Sports: The Average Fan Faces a Shutout, CHI. TriB., Jan. 18, 1992, at C1. Professional baseball players earn an average of $\$ 880,000$ annually, more than the average corporate CEO. Martha Moore, Making Baseball a Whole New Ballgame: The Man Behind the Mega-Salaries, USA TODAY, Aug. 5, 1991, at BS. The average salary for players in the National Football League increased to approximately $\$ 422,000$. Tinnothy Smith, Pro Football: Will Open Job Market Lead to Open Minds?, N.Y. TIMES, Dec. 29, 1991, § 8, at 2 .

59. See Ehrhardt \& Rodgers, supra note 4, at 640-43.

60. The estimates vary widely. See John Bannon, Ex-Agent: 'No Clean Programs,' USA TODAY, Dec. 17, 1987, at Cl (former agent estimating 20\%-80\%); Neff, supra note 26, at 36 (quoting Robert Berry, a Boston College law professor who has worked with college football players, as estimating that $50 \%$ of top college players receive some type of payment in violation of NCAA rules).

61. See supra note 10 and accompanying text. As NCAA administrator Rick Evrard expressed the problem: "We have jurisdiction over the schools and jurisdiction over the athletes, but the real problem is the third party we can't control-the agents." Former Sports Agent Charges College Players Signed Contracts, USA TodAY, Dec. 16, 1987, at C9.

62. Former agent Mike Trope expressed his view of the NCAA rules: "The rules are ridiculous, and they're not being followed by anybody. ... Why should I honor the NCAA rules when I'm not even bound by them?" Johnson \& Reid, supra note 32, at 30. 
enforce [its rules]. I'll sign a sophomore if I want."63 Although Bloom was correct that the NCAA cannot sanction agents for violations of NCAA rules, he underestinnated the powers of a creative prosecutor who gave the NCAA rules the force of the criminal law through the mail fraud statute.

\section{B. The Student-Athlete}

One by one, thirteen former college football players from eight schools took the stand and confirmed their participation in the plan of Walters and Bloom. ${ }^{64}$ The football players adnitted to having knowledge of the NCAA eligibility rules from the start of their careers. Many of the players admitted that the athletic departinent also informed thein of the eligibility rules. ${ }^{65}$ The players knew that by signing a representation contract with agents and accepting money and gifts they were violatmg NCAA rules and were placing themselves at risk of losing their college ehgibility and scholarships. ${ }^{66}$ Despite their knowledge of the NCAA rule violations and consequences, some fifty-eight players accepted the agents' offer. The players concealed their arrangennents with the agents. They hed on required eligibility forms to their schools and athletic conferences. ${ }^{67}$ Moreover, some players hed to coaches when asked whether they signed with Walters and Bloom. ${ }^{68}$ They continued to play college football, although, under NCAA rules, they were technically ineligible to coinpete.

Like the agents, the players were threatened with prosecution for mail fraud due to their involvement in the plan. To avoid prosecution, 69

63. Selcraig, supra note 50, at 25 (quotation omitted).

64. The players who testified were Romie Harmon and Devon Mitchell, University of Iowa; Robert Perryman and Garland Rivers, University of Michigan; Alvin Miller and Robert Banks, University of Notre Dame; Mark Ingram, Michigan State University; Anthony Woods, University of Pittsburgh; Edwin Simmons and Everett Gay, University of Texas; Paul Palmer, Teniple University; and Maurice Douglass, University of Kentucky.

65. See Transcript at 594 (testimony of Mitchell) (stating that school gave players rule sun1mary sheets).

66. See, e.g., id. at 145-49 (testimiony of Harmon) (describing the plan to keep their deal secret so that Iowa and the NCAA would not discover the rule violation and declare Harmon ineligible to compete); id. at 1014 (testimony of Banks) (admitting that he knew that by signing the representation contract and accepting inoney he was at risk of losing his scholarship at Notre Dame).

67. The players certified that they were eligible by signing their names to the "National Collegiate Athletic Association Student-Athlete Statement," 1985-1986 Acadenic Year, ff 5, which stated: "I am not aware of any violations of NCAA regulations involving ine and my institution." Id. at 169.

68. Robert Perryman bed to Coach Bo Schembechler at Michigan when he denied any contact with the agents. Perryınan stated that he hed "because I was advised to do it because, I-I mean, I had no other ties to Bo. I didn't have to tell him the truth anyway." Id. at 731.

69. One player, Cris Carter, was proseeuted for inail fraud and obstruction of justice for lying to the grand jury during Walters and Bloom's investigation. Carter pled guilty and was sentenced to 
the players entered imto pre-trial diversion programs, imcluding: (1) repaying the schools the scholarship money for the time that the players were ineligible; (2) performing community service work; and (3) testifying truthfully at trial..$^{70}$

1. The Decision to Take the Risk. Given the serious consequences that the players faced for violating the NCAA rules, what motivated their decisions to accept the risk? The trial exposed several explanations. The most common reason in the players' testimony is that they could not resist the opportunity to have money for their present use. As college athletes, the only compensation they received was scholarship money. ${ }^{71}$ Yet the players knew that they could command high salaries in professional football. For example, Ronnie Harmon signed a \$1.4 milhon contract with the Buffalo Bills upon leaving the University of Iowa. ${ }^{72}$ In the players' minds, they were just borrowing agamst their future earnings. ${ }^{73}$ They intended to repay the agents from their professional salaries. ${ }^{74}$

In addition, the players cited a present need for the money that the agents offered. Athletic scholarships do not cover the full cost of an education. Although tuition, room, board, books, and fees are included, the

three years' probation, fined $\$ 15,000$, and ordered to perform 600 hours of community service work over a three-year period. See Probation for Cris Carter, N.Y. Times, Apr. 25, 1989, at D28.

70. Transcript at 113; Chambers, supra note 19, at 1.

71. Athletic scholarships are limited to room, board, tuition, books, and other approved expenses. Generally, the student-athlete will be declared ineligible if he receives funds from sources outside the institution, unless the source of aid falls within one of the enunierated exceptions. See NCAA CONST. art. 3, $\$ 4$, reprinted in NCAA MANUAL, supra note 8, at 19-23. The sources to which the student-athlete can look to for additional aid include (1) family members or a legal guardian, (2) awards for educational expenses that do not include athletic ability as a major criterion, (3) awards for educational expenses that meet certain criteria if athletic ability is one of the factors considered, (4) other scholarships or educational grant in aid that do not conflict with NCAA rules, and (5) loans against potential future earnings for the exclusive purpose of purchasing insurance to cover an injury that would prevent the athlete from pursuing his professional career. Id.

A student-athlete in a financial bind who wanted to borrow money froin a bank against his probable future earnings may be prohibited from doing so by NCAA rules. Father Hesburgh of Notre Dame testified that Notre Dame would look very suspiciously at a student who borrowed money froin a bank, and that such action would probably constitute a violation of NCAA rules. Transcript at 994.

72. Walters v. Harmon, 516 N.Y.S.2d 874, 906 (Sup. Ct. 1987).

73. See Transcript at 1751 (testimony of Gay); id. at 1593 (testimony of Woods); id. at 559 (testimony of Mitchell). Borrowing against one's future earnings is common in our society and not generally looked upon with disfavor. Law firms, for example, often make advances to law students based on the students' future salaries.

74. The obligation to repay the agents was contingent upon the player entering professional football. The agents appeared to keep their word. Alvin Miller was injured and did not play professional football; the agents did not require him to pay back approximately $\$ 4500$ advanced to him. See id. at 908. 
awards do not provide a monthly allowance for incidental expenses. The scholarships do not provide enough money for some student-athletes with special needs. For example, some players had to support a family. ${ }^{75}$ Other students did not have financial resources for their everyday needs. ${ }^{76}$ Because many of the players came from economically disadvantaged backgrounds, they could not depend upon their families to help them with these everyday expenses. Moving beyond the players' individual needs, some felt compelled to give financial assistance to needy parents and siblings. ${ }^{77}$ The money enabled some players' parents to travel to bowl games. ${ }^{78}$

The common explanations given by the college players for accepting money from the agents-borrowing agamst future earnings and need (whether real or discretionary)-suggest a deeper reason for the players acceptimg the risk of entering imto agreements with the agents. Namely, many of the athletes did not accept the label of "amateur" placed upon them by the NCAA. College football is the recognized training ground for young football players who aspire to play in the professional ranks. Thus, the attitude of many players, schools, and members of the public is that the players are really professionals-in-training who deserve better compensation. ${ }^{79}$

The players also felt that their actions did not rise to the level of a crime. The players admitted that they had violated NCAA rules, but demied that in so doing they defrauded the umversities or cheated them of scholarship money. ${ }^{80}$ There are several explanations for why the players felt that their actions were not criminal. First, family members were

75. Devon Mitchell was married and had a child to support. Id. at 559. Robert Perryman also had a child. Id. at 712 .

76. Robert Banks, who played for Notre Dame, stated that he needed the money to buy new clothes after outgrowing his old clothes as a result of football conditioning. See id. at 1027-28.

77. Many of the players came from low-income families; thus, the money was very helpful. See id. at 905 (testimony of Miller) (stating that he used the inoney for his father's funeral and to help out his sister and family); id. at 719 (testimony of Perryman) (stating that he helped out his inother with the money); $i d$ at 1492 (testimony of Ingram) (stating that he helped with family expenses).

78. The agents paid for Garland Rivers's mother to watch her son play for Michigan in the Rose Bowl. Id. at 1391. See also id. at 1494 (agents paid for family meinbers of Michigan State's Mark Ingram to travel to bowl games).

79. See, e.g., Tom Farrey, Should College Athletes Share the Wealth They Help ProduceKnight Commission Did Not Answer Question of "Amateur Athletics," SEATTLE Times, Apr. 1, 1991, at Cl. In response to the Knight Commission's report addressing probleins in college sports, Wilham Gerberding, President of the University of Washington, stated: "I'd just like to see a recognition of the fact that these are semi-professional athletes." Id. Sonny Vaccaro, head of a prestigious basketball camp in New Jersey that attracts the top college recruits in the country, commented: "If I were one of these players, I'd say to hell with the NCAA. I'd take the inoney from the booster, because I'd feel I deserve it." Id.

80. For example, on cross-examination, Ronnie Harmon stated that he did not think he was guilty of fraud, but adinitted to being guilty of "accepting inoney." Transcript at 262 . Rivers felt 
often included in their decisionmaking process. ${ }^{81}$ Perhaps the presence and involvement of family inembers affected the players' feeling that their actions were not criminal. Second, the players inay have felt that they deserved the money, given the fact that their athletic efforts often produced large revenues for the schools. Common sense reveals that bigtime college athletes are constantly boinbarded with images of money from their sport. 82 The NCAA rules themselves send conflicting messages to the student-athletes. On the one hand, they proclaim that the student-athlete is an ainateur; on the other hand, they perpetuate the celebrity and inoney image of college sports by allowing players (and NCAA officials) to take certain all-expense-paid trips for publicity and awards purposes. ${ }^{83}$

The trial revealed that many of the players did not have misgivings about breaking the NCAA rules. Many players expressed concerns about being caught by the NCAA or their schools, but they were primarily concerned about protecting themselves rather than the adverse consequences that might befall teammates or the school. ${ }^{84}$ Once the players realized that they could conceal the deal, they were generally quick to accept the agents' offer. ${ }^{85}$

that he had already been punished-"I lost my scholarship and didn't get to wear my Big 10 ring." Id. at 1395.

81. See id. at 636-38 (testimony of Woodson) (stating that his mother showed some concern about NCAA violations); id. at 1359 (testimony of Rivers) (mother was present at meeting with agents).

82. As one former college football player expressed it:

The players see what is going on. They see the full stands. They see the TV cameras, the souvenirs, the cash registers. They sense that something unjust is going on. I certainly did. I reunember running into Ohio Stadium with my Northwestern teammates to a deafening boo froin 88,000 Ohio State fans and thinking that college football is so much bigger than the simple extracurricular activity people told ine it was. If my teammates and I were only amateurs, why was this game such a big deal to so many paying adnlts?

Rick Telander, Something Must Be Done, SPORTs IllustraTED, Oct. 2, 1989, at 95.

83. One such example is the NCAA-approved annual Playboy Magazine awards in Florida. On cross-examination, Father Hesburgh of Notre Dame stated that he was not aware that two Notre Dame players accepted an all-expense-paid luxury trip to Florida sponsored by Playboy Magazine. Father Hesburgh felt confident, however, that the trip was allowed by the NCAA rules and did not coustitute improper financial aid received outside the university. Transcript at 997, 1001-02.

84. See id. at 1567 (testimony of Woods); see also Neff, supra note 26, at 39 (reporting that one player saw no risk in accepting the agents' offer: "Where is the risk? If I got caught by one of the coaches, do you think they wonld tell on me? No way.").

But, by playing while ineligible under NCAA rules, the players subjeeted their schools and teammates to risks. For example, if the school had had reason to suspect the rule violation, the school could have been sanctioned by the NCAA and lost substantial revenues. Coinpeting with an ineligible player raised the possibility that an individual game would be forfeited, and, if the violation was disclosed after the season, the team could have been stripped of its winning record. Furthermore, the school could have suffered from a loss of goodwill with the public and with future recruits.

85. Neff, supra note 26, at 39 . Soine players turned down Walters and Blooin. One such player explained, "[Walters] told ine he understands the soul of a black inan. I think it was their pocket he 
2. Manipulators vs. Manipulated. Much of the public's perception of agents is negative. ${ }^{86}$ People commonly view agents as shady characters, out to take advantage of innocent and naive college athletes. Although the trial of Walters and Bloom often confirmed this image, it also sent a conflictimg message: Often, the players are sophisticated and opportunistic actors.

On the one hand, the trial confirmed the vuhrerability of the student-athletes. The secret nature of the contracts, combined with the players' youth and mexperience, did not provide the best setting for a fair exchange between parties. Because of their youth, the players may have been especially attracted to Walters's sales pitch. Walters introduced himself as the "agent of the stars." 87 Walters emphasized that he was the agent for many black entertainers, and that he could "enhance the stature of black athletes." $88 \mathrm{He}$ promised to take the players to concerts and parties with famous entertainers.

As college students, the players had mimimal spending money. Furthermore, many of the athletes came from low-income families. Unlike some college students with financial resources, many of the players could not afford to participate in standard college activities. They could not afford a car like many of their college classmates. Many of their parents could not afford to travel to watch their sons compete. Thus, when the agents spread hundreds of dollars in cash in front of the athletes, the temptation (or necessity) proved to be too great. As Maurice Douglass, one of the college players who accepted the agents' offer, explained: "It [sic] wasn't going up there [New York] to sign and take these guys [sic] money but when they put the money out there in front of me, you put $\$ 2500$ out in front of any kid in college, he'll take it right now."89

Furthermore, the players were unsophisticated when it came to bargaining for a representation contract. One player stated that he "didn't have a chance to think, [Walters] was talking so fast";"90 another stated that Walters would not let him read the contract, but read it to the player and his mother. ${ }^{91}$ They had never before signed or negotiated a contract

understood." Id. Others took some time to think about the decision, weighing the benefits and risks. Others, such as Simmons, jumped at the opportunity without much thought: "The minute lie opened the briefcase I said, 'Gimme the pen!' "Id. A majority of the college football players who were contacted accepted the agents' offer.

86. For a chromicle of the derogatory terms used to describe agents, see Ehrhardt \& Rodgers, supra note 4, at 634 (describing them as "vipers, parasites, charlatans, vultures, bloodsuckers, and leeches").

87. Neff, supra note 26 , at 37 .

88. Transcript at 711.

89. Id. at 1336.

90. Neff, supra note 26 , at 40 .

91. Id. 
such as the one presented by Walters and Bloom. ${ }^{92}$ Few, if any, had a lawyer review the contract before signing..$^{93}$

In fact, according to Mike Duberstein, director of research for the National Football League Players Association (NFLPA), the contracts were "atrocious." 94 They typically gave the agents full power of attorney over the financial matters of the player.95 They did not conform to NFLPA guidelines. For example, the contracts typically gave Walters, up front, six percent of the total value of the NFL deal sigued by the player (imcluding player bonuses). ${ }^{96}$ The contracts also gave Walters and Bloom ten percent of endorsement imcome. ${ }^{97}$ This figure for endorsements, however, is lower than average. 98 It appears that the players were more interested in keeping the agreement secret and in getting their money than in negotiating the terms of their contracts. ${ }^{99}$ Although there is no guarantee that the players would have functioned better and secured more favorable contracts when their college ehgibility expired, ${ }^{100}$ there is a reasonable chance that some players would have consulted with other agents and advisors to ensure that they were getting the best arrangement.

In perhaps the most graphic example of the players' vulnerability, the trial confirmed rumors that the agents threatened some players with physical violence upon learning that the players switched agents. One player testified that Bloom had threatened to break his legs. ${ }^{101}$ Another

92. See Transcript at 156 (testimony of Harmon); id. at 715 (testimony of Perryman).

93. See id. at 156 (testimony of Harmon); Neff, supra note 26, at 40.

94. Neff, supra note 26 , at 40 .

95. Id.

96. The NFLPA guidelines state that a player should never pay the agent a percentage of his entire contract, but should pay him yearly; the percentage should drop each year (10\% the first year, $5 \%$ the second year, $2 \%$ the third year, and none thereafter); and the percentage should be calculated only from that portion of the player's salary over the NFL mimimum for that year. Id.

97. Id.

98. See Robert H. RuXiN, AN AtHLete's Guide To Agents 112 (1989) (noting that agents typically demand a 20\%-25\% eudorsement fee).

99. Edwin Simmons, however, bargained with the ageuts over the initial amount of payment (evidenced by a promissory note), and was successful in getting $\$ 4000$ instead of $\$ 2500$; he stated that $\$ 2500$ was not worth the risk. Transcript at 1701 .

100. See Dunn, supra note 10, at 1031-37 (discussing exainples of agents who have mismanaged and taken advantage of unsuspecting athletes despite the fact that the agreements were entered into after the players' college eligibility expired).

101. Maurice Douglass testified that after switching agents, he received a phone call froin Bloom: "[Bloom] told me that if I did not return the money and the cars that he would have somebody rough me up and I might uot make it to the draft. . . . He said that he may have somebody break my legs." Transcript at 1292. 
player testified that Bloom had threatened to use underworld connections to inake sure that he never played football again. ${ }^{102}$

Although the players do appear vulnerable in many respects, there is another side to the story. Few of the players paid back any of the money advanced by Walters and Bloom, despite the fact that the players signed promissory notes for a portion of the money and understood that they were to pay back the entire amount. On cross-examination of Ronme Harmon, defense counsel suggested that Harmon "took the famous Norby Walters to the cleaners" by returning only $\$ 5000$ of the $\$ 54,000$ advanced to him. ${ }^{103}$ Most of the players walked away with money in their pockets. Although Maurice Douglass eventually repaid Walters, he testified to committing to two agents at the same time and accepting money from Walters when he did not have a good faith intention of keeping him as his agent. ${ }^{104}$

Furthermore, the trial revealed that few, if any, of the players had repaid their schools in accordance with their pre-trial diversion agreements with the government. ${ }^{105}$ More than a year after the trial, an investigation revealed that less than half of the athletes had made the

102. Edwin Simmons testified that Bloom called to warn Simmons and teammate Gay not to leave Walters, or "we can make a phone call to Las Vegas to get some people to come down and make sure Everett Gay doesn't play football again." Id. at 1706. On cross-examination, however, Simmons admitted that he and Gay "laughed" and "joked" about the threats, did not call the police, and that Simmons did not change his phone number. See id. at 1728-29.

103. Id. at 205. Consider the following exchange:

Q: Let ine ask you. Out of this transaction in which they are supposed to earn a profit of representing you, you made a profit of $\$ 49,000$, am I correct?

A: It was an investinent for thein.

Q: And an investinent for them for you to take $\$ 49,000$ froin them?

A: Well, he said he was gambling on me. I didn't say I was gambling on hin.

Q: He was gambling on you that you would be straight with him and that he would be allowed to negotiate your professional service contract, is that a fair statement?

A: No. No.

Q: Isn't that what his gainble was, is that you wouldn't stiff him at the last minute and hire another agent?

A: I don't think I stiffed him. What do you mean when you say "stiffed him?"

Q: Did you end up with $\$ 49,000$ of his money?

A: Of his money, that he invested in me?

Q: Yes.

A: Yes.

Id. at 205-06 (emphasis added).

104. See id. at 1317,1322 . The practice of stringing along several sources of money appears to be quite common:

"We all know that you take money from these guys but you don't have to go with them in the end. Play out the string. String them along. Take all the money he's going to offer and just quit him when there's no more. . . . Older players will tell you: Take inoney froin agents, alumni, anybody who will give it to you; take all the money they'll give you."

Neff, supra note 26 , at 42 (quoting William Harris).

105. For criteria of the pre-trial diversion agreements, see supra text accompanying note 70. 
payments to their schools. ${ }^{106}$ Because of these revelations about the athletes' questionable behavior, it is difficult to conclude that they are always naive and innocent actors.

3. Other NCAA Rule Violations. Another element of the college sports world revealed by the players' testimony is the existence of other violations of NCAA rules. In addition to the rules that restrict agency contracts and payments, other rules that pertain to academic standards must be met for a student-athlete to be ehigible to compete. ${ }^{107}$ The testimony of some players about the classes they took and their poor academic performances raised serious doubts as to whether these players satisfied the NCAA's academic standards. ${ }^{108}$ Other NCAA rule violations were disclosed at the trial. ${ }^{109}$ From the student-athletes' perspective, NCAA rule violations were not unusual.

\section{The University 110}

Along with the parade of athletes, several university officials-athletic directors, football coaches, and professors-testified at the trial.111 The universities were the alleged victims of mail fraud. The main purpose of the university officials' testimony was to illustrate how the schools were defrauded. The agreenients between the agents and athletes, which violated NCAA eligibility rules, served as the basis of the fraud. The university officials testified that they had informed the players about the NCAA ehgibility rules. ${ }^{112}$ They also confirmed that the

106. See John Gorman, 22 Fail to Repay in Scholarship Fraud, CHI. TRIB., Nov. 10, 1990, at C1.

107. See infra text accompanying note 115 .

108. See infra notes $118-25$ and accompanying text.

109. See Transcript at 589-94 (testimony of Mitchell) (admitting borrowing a car from an alumni booster); $i d$. at 1713-14 (testimony of Simmons) (acknowledging acceptance of a loan from his coach); id. at 1457 (testimony of Ingram) (admitting that he was convicted of and served time for a felony).

110. Although this Note uses the general term "university," often it is the athletic department within the university that has control over the many aspects of college sports. It is common for the athletic department to exist as an autononous organization, independent of the university. See generally SPERBER, supra note 2.

111. University officials testifying for the government included (1) Willie Fred Minus, Assistant Athletic Director at the University of Iowa, (2) Father Hesburgh, President Emeritus of the University of Notre Dame, (3) Robert King, Assistant Athletic Director at Purdue University, (4) Gwendolyn Norrell, retired professor emeritus from Michigan State University, (5) Joseph T. Marshall, law professor, Temple University, (6) Charles Theokas, Athletic Director of Tenple University, (7) Professor Liacouras, President of Temple University and law professor, (8) Glenn E. (Bo) Schembechler, Athletic Director and Head Football Coach, University of Michigan, (9) Steven Beering, President of Purdue University, and (10) Samuel Becker, professor at the University of Iowa.

112. Usually, the athletic department would hold a meeting at the beginning of the football season to go over the eligibility rules. See Transcript at 351-63 (testimony of Mims); id. at 1404 (testimony of King) (school tries to "pinpoint the ... danger areas"). 
players had turned in false eligibility forms. As a result, the schools certified to the local athletic conferences and to the NCAA that the players were eligible to coinpete, when in fact the players were ineligible. Each school official testified that the school would not have allowed their respective athletes to compete had they known of the representation and financial agreeinents. Because the NCAA sanctions apply only if the university could have reasonably known of the rule violation, ${ }^{113}$ the schools were not sanctioned by the NCAA for fielding ineligible athletes. The student-athletes competed for the sclools for the entirc season; yet, the government argued that the schools were nevertheless defrauded of scholarship property and the right to control this property-to award scliolarships to truly eligible athletes.

Thus, university adherence to NCAA rules was the cornerstone of the government's theory of the case. The defendants' strategy, on the other hand, was to illustrate thiat the scliools bent the NCAA rules when it was convenient for them to do so. Although the trial court limited the defendants' ability to obtain and present evidence of NCAA rule violations committed by the universities, ${ }^{114}$ defense counsels' cross-examinations of the university officials revealed numerous NCAA rule violations by the universities.

1. Violations of Academic Eligibility Rules. The trial disclosed that the NCAA academic eligibility rules were subject to the greatest abuse by the schools. The NCAA rules require that student-athletes meet three basic requirements to be academically eligible to compete: (1) student-athletes must be admitted as degree-seeking students according to published entrance requirements; (2) they must be in good academic standing in accordance with standards applied to all students; and (3) they must be enrolled as full-time students and making satisfactory progress toward a degree. ${ }^{115}$

The uriversity officials who testified used the right words about academic standards-they said tliat tlie players are at school "for an education first and forenost."116 Consider this statement made by the Assistant Athletic Director at Iowa: "One of the things we pride ourselves on is providing services once these students are here. Just getting them there is not what all it's about. We must retain them also, so we must provide the services that's going to lielp them meet the clrallenges

113. See NCAA Executive Reg. 1-3-(j), reprinted in NCAA MANUAL, supra note 8, at 188.

114. See infra notes 254-56 and accompanying text (discussing the pre-trial ruling restricting defendants' ability to present further evidence of NCAA rule violations by the schools).

115. NCAA CONST. art. 3, §3-(a), reprinted in NCAA MANUAL, supra note 8, at 19.

116. Transcript at $976-77$ (testimony of Father Hesburgh). 
of the university."117 Although some schools appeared to provide a healthy balance between academics and athletics, many schools clearly failed to live up to their words.

For example, im a scene that the press described as "painful," 118 the same Assistant Athletic Director at the University of Iowa who had earher praised the school's academic vigilance read through the transcripts of players Ronnie Harmon and Devon Mitchell. By the end of his jnnior year, Harmon had taken only one class toward his computer science major and was put on academic probation for poor academic performance. Each semester his grade point average was below a " $\mathrm{C}$." He was enrolled in inany "shide" courses. 119 Despite this record, the University of Iowa certified him as academically eligible-that is, that he was in good acadenic standing and making satisfactory progress toward his degree. ${ }^{120}$ During his fourth year, the school allowed him to play football, even though he was on academic probation and concerns were raised at the school that he was not working toward his degree.121 Devon Mitchell's academic record was similar. ${ }^{122}$

The academic record of Teinple University's Paul Palmer provides another example of a school's questionable adherence to NCAA academic rules. Palmer was certified as ehgible to coinpete each year despite the fact that he failed reniedial writing four times. ${ }^{123}$ Furthermore, it is doubtful that Palmer was maintaining progress toward a degree. After switching niajors at the start of his fourth year so he could be in techincal compliance with the rules, he dropped every class that year and "didn't

117. Id. at 348 (testimony of Mims).

118. See Steve Fiffer, Colleges: Defense Attorneys in Agents' Trial Put Spotlight on Colleges, N.Y. TIMES, Mar. 12, 1989, § 8, at 3.

119. The classes Harmon took in his first three years included teaching gym, officiating football, coaching basketball, bowhing, billiards, and watercolor painting. Transcript at 372-87.

120. Id. at 372 .

121. See id. at 387-90.

122. Mitchell's curriculum included karate, billiards, bowling, jogging, tennis, ancient athletics, recreational leisure, and advanced slow-pitch softball. Id. at 401-04, 585-86. Neither Harmon nor Mitchell returned to school after his athletic eligibility expired. See also Steve Wulf, Frosh Fracas, SPORTS ILlUSTRATED, Apr. 24, 1989, at 13 (discussing Iowa's einbarrassinent caused by the trial and Iowa president Hunter Rawlings's order for a crackdown on academic requirements for athletes-including a request to the NCAA to ban freshinen from athletic participation).

123. This disnal fact led Ralph Jenkins, director of the remedial writing and reading progran, to write in a menno to the athletic director: "Surely four failures in Remedial Writing must affect his eligibility." Transcript at 1811. Marshall affirmed in his testinony that the meino further pointed out that "if, God forbid, Palner were to win the Heisinan Trophy that it would be an enbarrassment to the university because of Palmer's acadenic record at the school." Id. at 1812. 
show up for a single exam when he finished playing football at Temple."124 Furthermore, the trial revealed that few of the players ever graduated from their institutions. ${ }^{125}$

Considering these examples, one must question how seriously the schools take the NCAA academic rules. Despite the contrary testimony of school officials, the examples illustrate that the schools do in fact bend NCAA academic ehigibility rules when it is convenient. The hypocritical behavior of the schools when it comes to academics is even more egregious when one considers that many of the athletes are recruited from underprivileged backgrounds, ${ }^{126}$ and that the athletic departments and schools make a great deal of money from their athletic programs. ${ }^{127}$

The schools are defensive about their academic records. An oftheard explanation is "you can lead a horse to water, but you can't make

124. Id. at 1818 (testimony of Marshall).

125. Only two of the players who testified at trial graduated-Notre Dame's Alvin Miller and Michigan State's Mark Ingram. Transcript at 899, 1443. Some of the players were close to finishing the work required for a degree; others, however, were woefully short, even after attending the school for four or five years. For a discussion of the abysmal graduation rates of black student-athletes, see Big-Time Athletes Coming Up Short, supra note 2, at C8.

126. The school officials testified that they regularly recruit athletes from disadvantaged economic and educational backgrounds. On direct examination, Mims from Iowa stated:

We actively encourage various areas within our university to go out and bring in students who will give diversity to the university. For example, our Special Support Services has a charge to make sure they have contact with culturally deprived individuals and make sure they have an opportunity to gain an education, and also for our student population in general to experience their being there at the university....

Transcript at 346.

Coach Schembeehler testified about his counseling efforts with Garland Rivers, who he thought came from a "lower income background": "When you take a young man from a fairly deprived background, ... you have to spend a little nore time with them and you have to counsel them a little more often. And so I had many meetings with Garland. And for three years, his progress was very good." Id. at 1830.

127. There were many questions at trial, to both players and academicians, about the amount of money made by the schools' athletic programs. The questions prompted Judge Marovich to respond as follows: "I don't know what this relevance is. But it's been dropped about on every witness, and if the jury by uow is not aware of the fact that these programs make money, I'm going to fall off this bench." Id. at 1416 .

Although athletic programs often lose money, see generally SPERBER, supra note 2; Koch, infra note 144, they also produce large revenues for many schools. Consider the estimated payment per team in the following 1989-1990 college football post-season bowl games:
1. Cotton Bowl
$\$ 3,000,000$
2. Fiesta Bowl
$\$ 3,000,000$
3. Orange Bowl
$\$ 4,100,000$
4. Rose Bowl
$\$ 5,500,000$
5. Sugar Bowl
$\$ 3,100,000$

The Lineups and Money for This Season's Bowl Games, CHron. HiGHer Educ., Dec. 13, 1989, at A53. 
him drink."128 Another excuse given by the universities is that many athletes are not primarily interested in getting an education. ${ }^{129}$ Despite these excuses, the university still has the responsibility to educate its student-athletes-especially when the university makes millions of dollars from athletic programs. For those student-athletes who come froin educationally and financially disadvantaged backgrounds, the schools have a heightened obligation to provide the niost supportive and encouraging academic setting. Although universities' efforts to create special support services should be applauded, ${ }^{130}$ these steps do not go far enough. The proper academic climate is vital to a successful academic program that addresses the special needs of some student-athletes. For niany studentathletes, the academic climate of their school is shaped by their contacts with figures in the athletic department. ${ }^{131}$ If the coaches indicate that it is acceptable--even preferable-to take easy courses, then the student often will take an easy course load.

Educators and school officials are in the position to stress the imiportance of an education and to create an atmosphere where academics are

128. An academic official at Temple made the following comment about Paul Palmer's academic performance: "And here we try to provide an educational opportunity, and he doesn't show." Transcript at 1818 (testimony of Marshall).

129. Indeed, many players testified that their primary purpose in attending school was to play football. See, e.g., id. at 760-61 (testimony of Perryman). Ronnie Harmon testified that if he wanted to, he conld have received a great or good education at lowa. He then explained, "I wanted an education but the school doesn't give it to you, I think it's totally up to you." Id. at 209.

130. The University of Iowa had several programs to help student-athletes: Summer Enrichment Program (intensified core courses for unprepared students prior to beginning freshman year); academic support services (tutors, study skill sessions, learning centers, and contacts with faculty to check student progress); and Minority Enrichment Committee for Student Athletes (guidance and encouragement to minority student-athletes). Id. at 346-49 (testimony of Mims). Despite these programs, the transcripts of Ronnie Harmon and Devon Mitchell reveal that they received a limited education during their five years at Iowa; neither graduated. See supra notes 118-22 and accompanying text.

131. Contrast Coach Schembechler's attitude toward academics at Michigan with Coach Fry's attitude at Iowa. Schembechler testified that he took a personal interest in his players' academic progress. He met with his players often, and when he did, he always had copies of their transcripts on his desk:

And the reason for that is that there is a tremendous correlation between academic performance and athletic performance.

And my background in coaching has always becn that-I've becn an academic counselor and I still am. And any coach that's worth his salt is. And so when I have a fellow like Perryman in to visit with me, I'm going to go over his academics as well as the other things.

Transcript at 1834.

When confronted with the suggestion that freshmen should be ineligible to compete, Coach Fry responded that he felt like the suggestion was "a slap in the face, not at football but to athletics in general." He went on to say, "Let ine coach football. Let the academicians run the school." Wulf, supra note 122, at 13 . This comment prompted the writer to comment: "We suggest that if Fry thinks a college coach's only job is to coach, then he should go someplace where he wouldn't have to worry that his players get an education. Say, the NFL." Id. 
taken seriously. ${ }^{132}$ This role of the university is important because college athletes, young and healthy, often fail to realize the importance of an education in later years. ${ }^{133}$ Many of these college athletes dreani of playing professional football; for many of thein, success in a sport has opened many doors that would otherwise be closed. Few college players, however, make it to the professional ranks. ${ }^{134}$ Unfortunately, many former college athletes wake up to a harsh reality-they inust go out into the world without basic educational skills and without a college degree. Because inany of the big-tine college athletes are black, this harsh reality has been especially felt in the black community. ${ }^{135}$ This situation has prompted some former athletes to bring claims for education malpractice against their forner universities. ${ }^{136}$

132. As Professor Liacouras testified regarding the discussions he has with student-athletes: "With respect to the young student athletes, women and men, the message invariably is the same, you're here first to get an education, we are giving you an opportunity, we are going to give you academic support, but it's up to you, we'd like to win every game, but sooner or later, your careers are going to be over in sports and it's what you do in school that's going to carry you forward." Transcript at 2179 (einphasis added).

133. Paul Palmer recognized in hindsight the importance of education: " 'I'm the first to adinit that I did not apply myself. . . I I wish I had. I put all iny eggs in one basket: football. It scares me now. Suppose something had gone wrong anywhere along the line. . . I know I'd tell the next guy to come along, "Go to class. Make sure you can conduct your life without football." " Michael Wilbon, Slippery Footing for Palmer: Running Back Tries to Halt Downward Trend of Events, Wash. Post, Nov. 3, 1989, at B1.

134. SPERBER, supra note 2 , at 8 (noting that the vast majority of big-time college athletes want to pursue professional sports careers, but that few make it).

135. See Big-Time Athletes Coming Up Short, supra note 2, at C8 (reporting the low graduation rates of minority athletes competing in big-time college sports). Twenty schools reported that they recruited 10 or more minority male athletes between 1980 and 1984 but graduated one or none: California State (Fullerton); McNesse State; North Carolina State; Wisconsin; Alabaina; Colorado; Long Beach State; Maryland; Louisiana State; Southern Alabama; Clemson; Iowa State; Wichita State; Northeast Louisiana; Arkansas-Little Rock; Middle Tennessee State; Tennessee Chattanooga; Arizona; Bowling Green; and Kansas. Id.

The black community has begun to address the problem of "sham" educations. Arthur Ashe called for a boycott among black athletes of schools that do a poor job educating their athletes. See Douglas Lederman, Panel Examining Blacks and Sports Discusses Possibility of Boycotting Colleges That Fail to Educate Black Athletes, CHron. Higher Educ., Apr. 25, 1990, at A36.

136. See, eg., Ross v. Creighton University, 740 F. Supp. 1319 (N.D. 11l. 1990). The court dismissed Ross's tort and contract claims against his school for failure to state a claim upon which relief could be granted. Ross's story is sad, and unfortunately quite colnmon. After four years at Creighton on a basketball scholarship, Ross had earned only 96 out of 128 credits required to graduate and maintained a " $D$ " average. Id. at 1322. Furthermore, he read at a seventh-grade level and his overall language skills were at the fourth-grade level. Id.

The court sided with the weight of judicial authority in dismissing Ross's education malpractice claim, noting that "in education [as opposed to other professions such as lawyers and doctors], the ultimate responsibility for success remains always with the student." Id. at 1328. Ross argued that the court should recognize a special tort of educational malpractice for student-athletes who, but for their athletic ability, would not have been admitted to the university because they lacked the acadeinic requirements, and once admitted, were not truly educated but only minimally educated to maintain athletic eligibility to compete. See id. at 1330 . The court rejected this argument, stating 
2. Other NCAA Rule Violations. The trial revealed other evidence of NCAA rule violations involving the universities. The governinent intended to call former Southern Methodist University football player Ron Morris as a witness to testify to the threats he received froin Walters and Blooin. After the court ruled that the defense could question Morris about receiving substantial sums of money from "university officials" before attending SMU and during his entire college career, however, the government did not call Morris to the stand.137 Edward Simmons, who also played for SMU, testified to receiving a loan froin his coach in violation of NCAA rules. ${ }^{138}$

Furthermore, the NCAA rules allow colleges the right to terminate or reduce aid if the student "engages in serious misconduct warranting substantial disciplinary penalty." 139 Despite this rule, a football player at Michigan State who had been convicted of a felony and had served time in jail was allowed to conpete for the school.140 Although the rule is written in discretionary language, ${ }^{141}$ the fact that a convicted felon was

that although it may redress a wrong (assuming that Ross was exploited), since schools seek to protect themselves from lawsuits, other marginal students' chances of admission would be endangered. Id.

Ross's contract claims were likewise dismissed. The court held that although Ross had a contractual relationship with Creighton by virtue of his scholarship, "the quality of Creighton's instruction of Ross cannot be attacked on contractual grounds." Id. at 1331. Furthermore, the court failed to read into the contract an inphed duty of good faith and fair dealing. The court noted that even though it had discretion to recognize such a duty, it felt that "it should leave the supervision of college athletics to private regulatory groups such as the NCAA, which presumably possesses the staff and expertise to carry out the job." Id. at 1332 (emphasis added).

As the Walters and Bloom trial illustrates, this presumption that the NCAA will appropriately regulate college athletics so that athletes are given a true opportumity to receive an education must be questioned.

137. Transcript at 1552-59. The government did not list SMU as a victim of mail fraud. The court ruled that because it was relevant to Morris's credibility, defense counsel would be allowed to question Morris about receiving money from SMU and signing false eligibility statements prior to meeting Walters and Bloom.

SMU was sanctioned by the NCAA for paying $\$ 61,000$ (money the school had received from a booster) to football players beginning in 1985. SMU was barred from playing football for a year, and restricted in its competition for the following year. See Douglas Lederman, NCAA Bars Football at Southern Methodist for Year: Penalties Are the Toughest Ever, ChroN. Higher Educ., Mar. 4, 1987 , at 1.

138. See Transcript at 1713-14.

139. NCAA CONST. art. 3, § 4-(c)-(2)-(iï), reprinted in NCAA MANUAL, supra note 8, at 22.

140. Mark Ingram was convicted of a felony for burglarizing dorm rooms of other students. He pled guilty and was sentenced to a 90-day jail sentence, of which he served 30 days during his junior year. He was also arrested for theft between his freshman and sophomore years and had been disciplined by the school for another incident. Transcript at 1534-35; see also Who's on Trial?, SPORTS ILLUSTRATED, Mar. 29, 1989, at 16.

141. In relevant part, the rule reads: "Aid may be gradated or canceled if the recipient ... (iii) engages in serious misconduct warranting substantial disciplinary penalty ...." NCAA CoNST. art. 3, § 4-(c)-(iii), reprinted in NCAA MANUAL, supra note 8, at 22. 
certified eligible to compete led one observer to query: "What does it take to get your scholarship revoked at Michigan State?"142

3. The Motivation for Ignoring NCAA Rules. The trial confirms the daily newspaper stories that the NCAA rules are continually violated at universities, often with the knowledge and participation of the university. ${ }^{143}$ Just as the player risks NCAA sanctions when he breaks a NCAA rule, the universities are also subject to hefty sanctions. What inotivates their decision to take the risk of NCAA sanctions? The trial suggests at least two factors-(1) economic motivations and (2) the desire for public recognition. College sports is a inoney-making enterprise for the college, especially for its athletic department. ${ }^{144}$ Television coverage of college games has astronomically increased revenues. Coaches demand high salaries. There is incredible pressure to win to inake money; ${ }^{145}$ thus, if a star player is breaking a NCAA rule, there is great temptation for the athletic department to ignore it, especially if it believes that no one will detect the violation. In a more aggressive move to gain a competitive advantage, soine wilfully violate the NCAA rules to recruit the best players. ${ }^{146}$ A winning season may not only lead to more revenue for the school, but it may also lead to greater public recognition.

Ms. Gwendolyn Norrell, retired professor emeritus at Michigan State, testified that the school used its discretionary authority im allowing Mark Ingram to compete in football. Norrell's position lead Walters's lawyer to ask the following question, to which Norrell answered affirmatively:

Q: Okay. Now, so then as I understand your testimony, it's okay under your rules, these discretionary rules, for a player to have been convicted of burglary-stealing from other students. That would not justify taking away his scholarship ... but if in fact he actually signed with an agent and accepted a legitimate loan that he was going to repay back, that would justify taking away his scholarship.

A: ... [T] [Tere are two different issues .... Under the NCAA and Big Ten rules, the student athlete cannot sign with an agent and be ehigible for scholarship aid and for eligibility. ... and [the misconduct rule] is a discretionary policy ... I think they are very different.

Transcript at $1540-41$.

142. Who's on Trial?, supra note 140, at 16.

143. For an overview of the abuse and corruption by umiversities in college athletics, see Lederman, 57 of 106 Universities in NCAA's Top Unit Punished in 1980's, supra note 1, at A31 (reporting that 57 of 106 universities competing in Division I were punished for violation of NCAA rules in the 1980s).

144. See James V. Koch, The Economic Realities of Amateur Sports Organization, 61 IND. L.J. 9 , 16 (1985) (stating that umversities "typically are interested in some form of . . . profit-maximization designed to wrimg maximum revenues out of inter-collegiate athletics"). See generally SPERBER, supra note 2.

145. The pressure to win can be enormous. For example, after several losing seasons, football coach Dick Crum at the University of North Carolina-Chapel Hill had his contract bought out by the Educational Foundation-a group of alumm. See, e.g., North Carolina Football Coach Crum Resigns After 5-6 Season, L.A. TIMES, Dec. 1, 1987, § 3 at 5.

146. See supra notes $137-38$ and accompanying text (discussing the NCAA rule violations at SMU). 
In the area of academics, schools may violate the NCAA standards because they believe that violations will not be detected. Although schools are put on probation for academic reasons, ${ }^{147}$ most of the NCAA investigations concern payments to athletes or recruiting violations. ${ }^{148}$ It is reasonable to conclude that the NCAA does not focus on policing academic rule violations as stringently as other rule violations. The trial evidence suggests that schools are more likely to bend the rules when it comes to academic qualifications, knowing that there is little chance that the NCAA will seriously enforce them.

\section{The NCAA}

Based on the foregoing discussion of the roles played by the agents, student-athletes, and universities, it should be apparent that the trial of Walters and Bloom was as much a trial about the rules of the NCAA. Although the NCAA did not fornally participate in the trial, ${ }^{149}$ the rules of the NCAA formed the cornerstone of both the prosecution and defense theories of the case. While the government tried to prove the sanctity of the rules, the agents tried to show widespread abuse and disrespect for the rules anong the universities-the "victims" themselves. By the end of the trial, it was clear that NCAA rule violations were common.

The frequency with which the NCAA rules are violated by schools and players casts serious doubt on the reasonableness of the NCAA rules theinselves. The NCAA and its rules have been the subject of much criticism and debate. ${ }^{150}$ The discussion has often extended to the legal arena. ${ }^{151}$ It is beyond the scope of this Note to address all of the criticisnis leveled at the NCAA rules, or to comment on the ultimate wisdom of a college sports system based on amateurism. However, the trial revealed at least three criticisins of the NCAA rules that nierit discussion: (1) The rules that restrict payment to the athletes create an artificial economic barrier between college and professional sports; (2) the rules are

147. See SPERBER, supra note 2 , at $295-96$.

148. See id. at $247-51$.

149. At least one commentator noted that the NCAA was "[t]he most significant nonparty" to the trial. See Chambers, supra note $19, \S 8$, at 1,8 . Others used the trial of Walters and Bloom to launch an all-out attack on the soundness of the NCAA rules in general. See, e.g., Rick Telander, $A$ Question of Fairness, SPORTS Illustrated, May 1, 1989, at 114; Telander, Something Must Be Done, supra note 82 , at 92.

150. See infra note 267.

151. See, e.g., NCAA v. Tarkanian, 488 U.S. 179 (1988) (holding that NCAA action does not trigger state action for purposes of constitutional analysis under the Due Process and Equal Protection Clauses); NCAA v. Board of Regents, 468 U.S. 85 (1984) (applying antitrust laws to some aspects of college football, such as the ability of member schools to sell rights to televise football games, but not to the amateur eligibility rules themselves); McCormack v. NCAA, 845 F.2d 1338 (5th Cir. 1988) (finding that NCAA eligibility rules are reasonable and do not violate antitrust rules). 
often unfair to the student-athlete, e.g., athletic scholarships do not cover the full cost of education; and (3) the rules are heavily weighted toward protecting the economic interests of the schools and the NCAA, rather than the interests of the student-athletes.

1. The NCAA Rules Create an Artificial Economic Barrier Between College and Professional Sports Markets. By erecting an artificial barrier with absolutely no flexibility between the market structures of professional and college sports, the NCAA rules have created an atmosphere that invites abuse. College athletes are "paid" only the value of their scholarships while professional athletes often command six-figure salaries. ${ }^{152}$ As professional salaries continue to rise, more pressure will be placed on the artificial economic barrier between college and professional sports.

Froin each of the actors' perspectives, there is great econoinic incentive to ignore the NCAA rules. By contacting college athletes before their college ehigibility expires, the sports agent has a better chance of representing the top college players-thus securing a bigger piece of the growing financial pie in professional sports. ${ }^{153}$ By accepting money and gifts froin sports agents, the student-athlete receives money and goods for his present use. ${ }^{154}$ By certifying student-athletes as academically eligible although they have failed to satisfy the NCAA educational requireinents, the schools are able to field their best athletes-thus the schools have a better chance of producing revenues froin their athletic programs and gaining public recognition. ${ }^{155}$

2. The NCAA Rules Are Often Unfair to the Student-Athlete. ${ }^{156}$ To the student-athlete, the NCAA rules and the college sports environment send conflicting signals. Many of the NCAA rules are unreasonable froin an athlete's perspective. As the trial illustrated, the scholarships awarded to college players are often not enough to meet the players' reasonable needs. ${ }^{157}$ For the student-athlete who needs the money, the NCAA rules and sanctions do not deter the student-athlete

152. See supra notes 57-58 and accompanying text.

153. See supra note 58 (average annual salaries for professional athletes).

154. See supra Part I(B).

155. See supra Part I(C).

156. The NCAA and the schools are not the only parties who seek to impose rules contrary to the student-athletes' best interest. Senator Bennet Johnston of Louisiana, for example, announced that he would support legislation to prevent college athletes from signing professional football or basketball contracts before their entering classes graduated. Johnston admitted that the impetus for this legislation was a rumor that LSU basketball star Chris Jackson was going to turn professional after his freshman year. See Telander, Something Must Be Done, supra note 82, at 105.

157. See supra Part I(B)(1). 
from accepting advances from agents. For example, despite the fact that Temple's Paul Palmer was stripped of all his awards and that Temple forfeited all six games that it won when Palmer was technically inehgible, Palmer stated he might make the same decision to accept the agents' money if given a second chance. Palmer commented:

I would like to think, "Well, I wouldn't do that again, given the choice." But I don't know that... The thing is, none of this is simple black and white. We all know that the NCAA rules are there. And if you break the rules ... you may have to pay for it. That doesn't change the fact that a lot of us weren't from silver-spoon families. There was no money coming from my household. ${ }^{158}$

Surely, a monthly allowance for an occasional movie, dinner, and other standard college fare is not unreasonable for student-athletes from economically disadvantaged backgrounds. In light of the revenues that bigtime college sports generate for the schools, it is appalling that athletic scholarships do not include spending money for students who need it. ${ }^{159}$

Furtliermore, the NCAA rules prohibit a scholarship athlete from getting a job during the school year. Although this is ostensibly in the athlete's best interest because of time demands from athletics and academics, ${ }^{160}$ a potential source of needed income to the student-athlete is removed. The NCAA rules flatly prohibit payment to the athlete that is connected with his athletic ability. Yet students who are gifted in other areas and receive scholarships are not restricted from receiving remuneration as a result of their special skills. ${ }^{161}$ As a result of the NCAA's unreasonable compensation provisions, the players are vuhierable to accept offers of payment from agents, boosters-anyone.

158. Wilbon, supra note 133. Palmer then goes on to describe what he did with the money he received from the agents, which mcluded supporting his grandmother and taking his teammates out to parties that other students could afford. He further commented, "You talk about athletes not being treated differently from other students. How come [NCAA] rules allow it that we can't order a pizza or go to the mall if our folks don't have much money?" Id.

159. Several proposals have inclnded such a stipend in athletic scholarships. One recently considered by the NCAA was rejected. The plan would have paid student-athletes a nominal sum from the bonanza of television revenues that the NCAA will receive from CBS to broadcast the Final Four basketball tournament. See Douglas Lederman, NCAA Budget Panel Backs Plan for Sharing TV Money, Chron. Higher Educ., July 18, 1990, at A38 (noting that the plan was eventually rejected in favor of using the money to try to enhance the academic performance of athletes).

160. In addition to the time demands of school work, a student-athlete is required to spend time on his sport. According to one source after extensive research, a Division I-A football player can spend as much as 60 hours a week on his sport while in season. See SpERBER, supra note 2, at 302 (citing study by Professor Harry Edwards, sociologist at the University of California, Berkeley). Fred Mims, assistant athletic direetor at the Umiversity of Iowa, estimated that the average studentathlete spends 30 hours a week on his sport. See Transcript at 453.

161. For example, students gifted in music can give unusic lessons; aeademically gifted students can earn income by tutoring. 
Another unreasonable rule from the players' perspective is the NCAA's restriction on agent-player contact to discuss representation of the athlete in professional sports. ${ }^{162} \mathrm{~A}$ player interested $\mathrm{m}$ a professional career nust wait until after his last college game before seeking an agent. Before that time, the player certainly has a legitimate business interest in investigating his professional market value. The player is allowed to talk with school officials ${ }^{163}$ and friends about his potential professional career. These sources of information, however, may not be the most helpful to the student-athlete. The student-athlete is in a contractual relationship with his school; thus, the school has a conflict of interest and will often shield important information from the athlete. ${ }^{164}$ Indeed, Robert Perryman cited this need for imformation as one of the reasons why he was mterested in Walters and Bloom in the first place. ${ }^{165}$

\section{The NCAA Rules Focus Too Much on Economics and Not} Enough on Academics. Despite NCAA rules estabhishing criteria for acadenic eligibility, the trial revealed that the NCAA tolerates schools that do not take seriously their obligation to educate student-athletes. ${ }^{166}$ One reason for this is that the NCAA rules are geared more toward protecting the economic interests of the NCAA and athletic departments of uriversities than the academic interests of the student-atlilete. 167 The hidden message to schools and players that academic shortcuts will be tolerated is arguably more detrimental to the student-athlete tlian taking inoney from an agent. The overemphasis of inoney and sports and the underempliasis of academics can devastate players' lives. Only a small percentage of college athletes go on to a successful professional sports career.

The NCAA's hypocritical beliavior toward academics is illustrated by its rejection of mitiatives that would strengthen the academic-athletic

162. See NCAA CONST. art. 3, § 1-(c), reprinted in NCAA MANUAL, supra note 8, at 10-11.

163. The NCAA rules allow "an authorized institutional career counseling panel" to meet with the student-athlete and representatives from professional teams to review a proposed professional contract. See id.; see also id. \$ 1-(h)-(4), reprinted in NCAA MANUAL, supra note 8, at 15.

164. Mike Trope, an agent and former college football player, has commented: "To assume that it's wrong for a player to seek an advisor before his last college game is to assume that his best interests are being looked out for by someone else, namely the school. That's a theory that the colleges like to promote. It's a false theory." "Telander, A Question of Fairness, supra note 149, at 114.

165. See Transcript at 769. Perryman stated that Coach Schembechler is "the kind of coach that hides those things, so you don't really know about your pro aspirations. And when I did talk to [Bloom], I mean, he had a lot of information about me and that's why I was really interested in him." Id.

166. See supra Part I(C).

167. See supra notes $147-48$ and accompanying text. Furthermore, consider the fact that the NCAA rules do not require that student-athletes ever graduate from their schools. 
nexus, and its failure to address academic problems called to its attention. ${ }^{168}$ For example, Senator Bill Bradley, a former student-athlete, was "absolutely flabbergasted by the opposition" of the NCAA to his proposal that the NCAA approve a bill requiring schools to reveal graduation rates for scholarship athletes. ${ }^{169}$ The benign purpose of the proposal was to enable a recruit to make an informed decision about which college to attend based on the school's commitment to education. ${ }^{170}$ Furthermore, some schools have challenged the NCAA to address their glaring educational shortfalls. ${ }^{171}$

While ignoring academic issues, the NCAA spends much of its time and resources considering econormic ones. It recently considered how to allocate the one-billion-dollar "bonanza" from the television rights to the Final Four basketball tournament. ${ }^{172}$ Given the money that the schools and the NCAA make from college sports, the lack of insistence on solid academic training of its student-athletes is especially egregious.

These three criticisms of the NCAA rules illustrate that far from providing solutions, the NCAA causes many of the problems in college sports. The negative impact of the NCAA rules can be seen im the behavior of each of the other three actors. Due to the artificial economic barrier between college and professional sports created by the NCAA rules, the agents pursued aggressive tactics to sign the best college athletes to representation contracts before the players' college eligibility expired. With insufficient funds to meet their special needs, yet realizing that soon they would earn millions of dollars as professional athletes, talented college athletes accepted the agents' offers. With the opportunity to garner

168. Recently, however, the NCAA appears to be addressing academic concerns. See, eg., Richard Demak \& William F. Reed, Reform School: The NCAA Gets Even Tougher on Athletes' Academics, SpORTs Illustrated, Jan. 20, 1992, at 7 (outlining new proposals).

169. Telander, Something Must Be Done, supra note 82 , at 92.

170. Id. After three years, a version of Bradley's bill finally passed in Congress. Student RightTo-Know Act of 1990, Pub. L. No. 101-542, $\S 101-105,104$ Stat. 2381-84 (codified at 20 U.S.C.A. $\S \S 1001,1092$ (West Supp. 1991)).

171. The faculty counsel at the Umiversity of North Carolina at Chapel Hill challenged the NCAA to adopt several proposals withm five years: (1) spending less time on sports; (2) granting fewer favors to athletes who do not have the grades to be admitted to the university; (3) declaring freshmen ineligible; and (4) linking scholarships to graduation rates. The faculty counsel declared that if the NCAA does not adopt these provisions, the university will adopt them unilaterally. Douglas Lederman, $U$. of North Carolina Faculty Council Pushes for Sports Reforms; Effort Could Set National Standard for Involvement of Professors, CHRON. HIGHER EDUC., Jan. 31, 1990, at A37; see also Athletic Notes, ChroN. Higher EDUC. July 25, 1990, at A29 (reporting proposal by Metro Atlantic Athletic Conference that a college lose membership in NCAA Division I should the graduation rate of scholarship athletes fall below $50 \%$ for two years in a row).

172. See Douglas Lederman, Heads of Big Time Programs Say They'll Cooperate with the Effort to Restore Confidence in College Sports, CHRON. HIGHER EDuc., June 20, 1990, at A36 (discussing ways to distribute the one-billion-dollar bonanza froin CBS to obtain the television rights to broadcast the Final Four basketball tournament from 1991-1997). 
large revenues and to strengthen their public recognition, the universities ignored the rules of the NCAA-especially the academic eligibility rules-to field their best players to increase their chance of victory.

Based on the roles of the actors mvolved in the Walters and Bloom trial, a clear message from the trial is that many actors contribute to the abuse and corruption in college sports. And although the trial clearly exposed the agents' unethical behavior, it also revealed questionable behavior on the part of the student-athletes, schools, and the NCAA.

\section{The Trend Toward Adopting the MaIl Fraud Statute}

The Walters and Bloom trial marks the first time that the federal criminal law has been used against sports agents who violate NCAA rules in recruiting athletes. ${ }^{173}$ The government argued that the agents committed mail fraud because (1) their scheme of signing college players to representation contracts and giving the players money and gifts in violation of NCAA eligibility rules defrauded the umversities of property, and (2) the mail system furthered the scheine because the players lied on NCAA eligibility forms that were inailed to athletic conferences. Althougli the government's new theory has been accepted by two courts, ${ }^{174}$ the trial of the sports agents raises serious questions as to the wisdom of expanding the mail fraud statute to target sports agents who violate NCAA rules.

This Part is divided into two Sections. Section A analyzes judicial acceptance of the government's theory of mail fraud. At the initial level of statutory interpretation, it is questionable whether sports agents who violate NCAA rules satisfy the legal elements of inail fraud. Furthermore, the trial of the sports agents revealed additional legal problems with the government's theory. More importantly, Section B argues that, based on the lessons of the Walters and Bloom trial, policy considerations militate against expanding the mail fraud statute-even if the government's theory is plausible. Expansion of the mail fraud statute should be rejected because (1) it invites public scorn for the law, (2) it leads to discriminatory enforcement, and (3) it wastes judicial resources. By focusing on a symptom of the problem rather than the problem itself, the mail fraud statute will do little to tliwart the abuses and corruption in college sports.

173. In one instance, a sports agent was prosecuted under a state criminal law in Alabama for tampering with the outcoine of a sports contest. See infra text accompanying notes 245-50.

174. United States v. Walters, 711 F. Supp. 1435 (N.D. Ill. 1989), rev'd on other grounds, 913 F.2d 388 (7th Cir. 1990); and United States v. Walters, 775 F. Supp. 1173 (N.D. Ill. 1991). 


\section{A. The Government's Theory of Mail Fraud in the Walters and Bloom Case: Stretching the Statute Beyond Its Limit}

1. Background of the Mail Fraud Statute. The mail fraud statute provides that it is illegal to use the mails "for the purpose of executing" a "scheme to defraud."175 Thus, there are two basic elements to the crime of mail fraud: (1) a "scheme to defraud"; and (2) use of the mails to "execute" the scheme. ${ }^{176}$ The broad language of the statute, along with the sparse legislative history of the original statute, ${ }^{177}$ has left the scope of the mail fraud statute to judicial interpretation. Through the years, courts have expansively interpreted the mail fraud statute.

The broad scope of the mail fraud statute has been the subject of much debate. On the one hand, the statute has been heralded as a catchall provision to fight against crime-the prosecutor's "first line of defense."178 Chief Justice Warren Burger cited the mail fraud statute as a valuable stop-gap measure that allowed crime to be punished before Congress had time to pass specific legislation. ${ }^{179}$ On the other hand, critics have faulted the expansive reading of the mail fraud statute because (1) it violates due process by subjecting defendants to criminal liability without fair warning that their actions are criminal, (2) it creates tension within the separation of powers doctrine, and (3) it raises the problems associated with "overcriminalization." 180

175. The mail fraud statute, 18 U.S.C. $\$ 1341$ (1988), provides, in relevant part:

Whoever, having devised or intending to devise any scheme or artifice to defraud, or for obtaining money or property by means of false or fraudulent pretenses, representations, or promises ... for the purpose of executing such scheme or artifice or attempting so to do, places in any post office... any matter or thing whatever to be sent or delivered by thc Postal Service... or knowingly causes to be dehivered by mail according to the direction thereon ... any such matter or thing, shall be fined not more than $\$ 1,000$ or imprisoned not more than five years, or both.

Id.

176. Id.

177. The original mail fraud statute was passed in 1872 and has undergone three major revisions; the latest revision oceurred in 1949. For a general discussion of the history of the mail fraud statute, see Donald V. Morano, The Mail-Fraud Statute: A Procrustean Bed, 14 J. MARShall L. REV. 45, 45 n.2 (1980); Jed S. Rakoff, The Federal Mail Fraud Statute (Part I), 18 DuQ. L. REV. 771, 779-86 (1980).

178. United States v. Maze, 414 U.S. 395, 405 (1974) (Burger, C.J., dissenting).

179. Burger pointed to four types of criminal behavior prosecuted under the mail fraud statute: (1) securities fraud (until passage of the Securities Act of 1933, 15 U.S.C. $\$ \S 77 \mathrm{a}-77 \mathrm{bbbb}(1988)$ ); (2) loan sharking (until passage of 18 U.S.C. $\$ \$ 891-896$ (1988)); (3) fraud connected with the sale of undeveloped land (until passage of the Interstate Land Sales Full Disclosure Act, 15 U.S.C. $\$ \S 1701$ 1720 (1988)); and (4) credit card fraud (until passage of 15 U.S.C. $\S 1644$ (1988)). Maze, 414 U.S. at 406.

180. See John C. Coffee, Jr., Hushl: The Criminal Status of Confidential Information After McNally and Carpenter and the Enduring Problem of Overcriminalization, 26 AM. CRIM. L. REv. 121 (1988) [hereinafter Coffec, Criminal Status of Confidential Information] (tracing the debate of overcriminalization and discussing the adverse consequences of overcriminalization in the context of employee misconduct regarding employer's trade secrets and confidential information); Daniel J. 
One hotly contested subject in the debate over the proper scope of the mail fraud statute was the developinent of the "intangible rights" doctrine. ${ }^{181}$ Under the "intangible rights" doctrine, the public was deemed to have a right in honest government. The doctrine was used to prosecute corrupt public government officials with mail fraud on the theory that they had "defrauded the public of its right to "honest government." "182 In 1987, the Supreme Court seemed to have resolved the debate over the "intangible rights" doctrine in favor of the critics with two decisions, McNally v. United States ${ }^{183}$ and Carpenter v. United States. ${ }^{184}$ In McNally, the Court held that the mail fraud statute extended only to schemes to defraud money or property. ${ }^{185}$ Thus, the Court reversed the convictions of government officials in Kentucky who allegedly diverted commissions from Kentucky's workers' compensation insurance business to forward their own financial interests. ${ }^{186}$ The Court stated that "[i]f Congress desires to go further, it must speak more clearly than it has."187 In 1988, Congress did just that by amending the mail fraud statute to define "scheme to defraud" to include "a scheme or artifice to defraud another of the intangible rights of honest services."188

In Carpenter, the Court fine-tuned the definition of property by holding that "McNally did not limit the scope of [section] 1341 to tangible as distinguished from intangible property rights."189 The Court upheld the mail fraud conviction of defendant $R$. Foster Winans, who had disclosed financial information from his "Heard on the Street" column in

Hurson, Limiting the Federal Mail Fraud Statute - A Legislative Approach, 20 AM. CR1M. L. REV. 423, 458 (1983) (advocating the need for "a concrete and comprehensible definition of the term 'scheme to defraud' " for the mail fraud statute to have clear and meaningful limits); Peter R. Ezersky, Note, Intra-Corporate Mail and Wire Fraud: Criminal Liability for Fiduciary Breach, 94 YALE L.J. 1427, 1440-46 (1985) (arguing that the overcriminalization of mail/wire fraud in the area of corporate executives has led to a usurpation of state control over corporate affairs); see also John C. Coffee, Jr., From Tort to Crime: Some Reflections on the Criminalization of Fiduciary Breaches and the Problematic Line Between Law and Ethics, 19 AM. CRIM. L. REv. 117, 143-44 (1981) (asserting that the expanded reading of the mail fraud statute may have a "chilling effect ... [on] participation in the political process").

181. For background on the development of the intangible rights doctrine and an argument for its elimination based on due process grounds, see generally Morano, supra note 177.

182. Rod J. Rosenstein, Recent Developments, Mail Fraud: Termination of the "Intangible Rights" Doctrine, 11 HaRv. J.L. \& PuB. POL'Y 286, 286 (citing McNally v. United States, 483 U.S. 350 (1987)).

183. 483 U.S. 350 (1987).

184. 484 U.S. 19 (1987).

185. See McNally, 483 U.S. at $356-60$.

186. For a discussion of the McNally decision, see Rosenstein, supra note 182.

187. McNally, 483 U.S. at 360.

188. Anti-Drug Abuse Act of 1988, Pub. L. No. 100-690, $\S 7603,102$ Stat. 4148,4508 (codified at 18 U.S.C. $\S 1346(1988)$ ).

189. Carpenter, 484 U.S. at 25. 
the Wall Street Journal to investors who traded on the information. The Court held that the Wall Street Journal had a property interest in the intangible property of confidential business information. It further ruled that a scheme to defraud under the mail fraud statute does not require "inonetary loss," but can consist of the deprivation of "exclusive use" of such property. ${ }^{190}$ In light of the Court's apparent restriction and refinement of the mail fraud statute in McNally and Carpenter, the government advanced its new theory of mail fraud against Walters and Bloom. ${ }^{191}$ This Note will now analyze judicial acceptance of the government's novel theory of the mail fraud statute in the Walters and Bloom case.

2. Judicial Acceptance of the Government's New Theory of Mail Fraud. The government's new theory of mail fraud was accepted by two courts as well as by the jury in the Walters and Bloom trial. In United States v. Walters (Walters I), ${ }^{192}$ the court rejected the defendants' motion to dismiss the mail fraud indictment on several grounds. The case proceeded to trial, where a jury found Walters and Blooin guilty of the mail fraud cliarges for two of the four schools named as victims. The agents' convictions were reversed on appeal and the case was remanded on account of trial error. ${ }^{193}$ The appellate court's decision did not comment on the government's mail fraud theory. As a result of the appellate ruling, Walters and Bloom were granted separate trials. In United States

190. See id. at 26-27.

191. Some observers question the narrowing effect of McNally in light of Congress's action and the Carpenter decision. For example, Professor Coffee described recent developments concerning the mail fraud statute as "old wine ... poured into new bottles." Coffec, Criminal Status of Confidential Information, supra note 180, at 152. McNally, however, lias not been overruled and lias been embraced by the lower courts. The purpose of Congress's act was to approve of the "intangible rights" doctrine that lrad been used to prosecute local government officials for corruption. Altlougl the language of the amendment is arguably broad enough to cover felds otler than corruption in government, it is unlikely that the amendment was designed to reacli college atlletics.

192. 711 F. Supp. 1435 (N.D. Ill. 1989), rev'd, 913 F.2d 388 (7th Cir. 1990).

193. See United States v. Walters, 913 F.2d 388 (7tlı Cir. 1990). The appellate court held that two trial procedures were sufficiently prejndicial to warrant reversal: (1) refusal of the trial court to instruct the jury on the advice-of-connsel defense for defendant Walters; and (2) denial of Bloom's motion for severance. See id. at 391. Defendants Walters and Bloom pnrsued different strategies at trial. Only Walters wanted to pnrsue the advice-of-counsel defense to prove that lie did not have the specific intent to defraud. Id. at 393. Such a tactic required waiver of the attorney-client privilege. Bloom objected in a motion for severance that Walters's defense strategy forced him to waive his attorney-client privilege. Id. at 392. The appellate court held that the attorney-client privilege was held by both Walters and Bloom. See id. Noting that "[t]le attorney-client privilege ranks high among the precious gems of our adversary system of justice," id. at 393, the court held that Bloom's motion for severance should have been granted. Id. 
v. Walters (Walters $I I),{ }^{194}$ a new court in the same district denied Walters's motion to dismiss the mail fraud indictinent for many of the same reasons expressed in Walters $I .{ }^{195}$

In Walters $I$, the defendants argued that their scheme did not satisfy the mailing element of the mail fraud statute. As stated earlier, one of the two elements of mail fraud is use of the mails "for the purpose of executing the scheme."196 The inailing requirement has been construed by the courts to mean that defendant inust have "caused" the mailing, and the mailing inust be "in furtherance" of the scheme. ${ }^{197}$ Defendants argued that they did not cause the mailings because neither they nor the student-athletes personally mailed the eligibility forms. ${ }^{198}$ The defendants further protested that the mailings were too far removed from the scheme to satisfy the "in furtherance" requirement. 199

The court held that Walters and Blooin inet both of these requirements. First, the court recognized the well-establislied rule that a defendant "causes" the use of the mails as long as sucl use was "reasonably foreseeable" to one in the defendant's position. ${ }^{200}$ The court held that the use of the mails was reasonably foreseeable because the student-athletes liad to sign ehibility forms that would be sent to the athletic conferences. ${ }^{201}$ However, the court did not discuss whether it was reasonably foreseeable for Walters and Bloom to know about these eligibility forms in the first place. This omission is a weakness in the Walters $I$ opinion. ${ }^{202}$ Second, the court ruled that the "in furtherance" requirement was satisfied because "the inailings of the documents . . . are an expected part of the scheme and the mailings clearly further the sclieme." 203 The court noted that a jury could reasonably conclude that

194. 775 F. Supp. 1173 (N.D. Ill. 1991).

195. See id. at 1180-81. Walters recently pleaded guilty to the two mail fraud charges to avoid a new trial based on more severe charges of racketeering and conspiracy. Matt $O^{\prime}$ Connor, Guilty Plea by Walters, CHI. TRIB., Dee. 19, 1991, § 6, at 6.

196. See supra notes $175-76$ and accompanying text.

197. See Pereira v. United States, 347 U.S. 1 (1954); Walters I, 711 F. Supp. at 1439-40. See generally Rakoff, supra note 177.

198. See Walters $I, 711$ F. Supp. at 1439.

199. See id.

200. See id. The court stated: "Where one does an act with knowledge that the use of the mails will follow in the ordinary course of business, or where such use can reasonably be foreseen, even though not actually intended, then he 'causes' the mails to be used." Id. (quoting Pereira, 347 U.S. at 8 ).

201. See id.

202. The "reasonably foreseeable" test of the mail fraud statute, commonly encountered in tort law, is an anomaly in criminal law. This standard leads to difficulties in applying the mail fraud statute. See Rakoff, supra note 177, at 773-79.

203. Walters $I, 711$ F. Supp. at 1440 (citing United States v. Murphy, 768 F.2d 1518, 1530 (7th Cir. 1985) ("It may be enough if the use of the mail is an ordinary or expectable event in the course of the scheme and the mailings further the scheme."), cert. denied, 475 U.S. 1012 (1986)). 
concealment was essential to the agents' scheme. ${ }^{204}$ If the schools had truthful information, they could have declared the athletes ineligible to compete. The court explained that such a situation "could seriously affect a particular athlete's value to defendants."205

Although the court seems to reason correctly that mailing the false ehigibility forms to the athletic conferences helped the agents conceal their plan, this focus on the mailing eleinent begs the question: Was the agents' plan a "scheme to defraud" as prohibited by the mail fraud statute? Even though there are weaknesses in the Walters $I$ analysis of the mailing element, it is equally important to focus on judicial treatment of the "scheme to defraud" eleinent.

Under McNally, the "scheme to defraud" must involve the deprivation of a protectible property interest. In Walters $I$, defendants argued that the mail fraud indictments should be dismissed because the agents' plan did not deprive the universities of property within the meaning of McNally. The court rejected defendants' McNally arguments. ${ }^{206}$ The court noted that the indictment alleged two types of property deprivation due to the agents' scheme: (1) inoney and property in the form of the scholarships; and (2) the universities' "right to control" the allocation of a limited number of scholarships to athletes. 207

The court in Walters $I$ reasoned that the first alleged property deprivation, the scholarship inoney and property, clearly satisfied the McNally requireinent. 208 The court rejected Walters's protest that the schools were not defrauded of the scholarship money or property because the

204. Id.

205. Id. The same "in furtherance" objection was made by Walters in Walters II; however, the court simply followed the reasoning of Walters $I$. After noting that few college football players relinquish remaining college eligibility to pursue a carecr in professional football, the court reasoned:

A player in his junior year of college is unlikely to have demonstrated the proven ability necessary to justify a lucrative professional contract. The fact that the players signed by defendant chose not to forego their senior year adds weight to this observation. If a player's prospect of signing such a contract was diminished because he was rendered ineligible to play intercollegiate football, defendant's commission under the representation agreement would be adversely affected. The players' misrepresentations concerning their eligibility were therefore "essential" ....

United States v. Walters (Walters II), 775 F. Supp. 1173, 1181 (N.D. I11. 1991).

206. See Walters $I, 711$ F. Supp. at 1442-46.

207. Id. at 1443. Specifically, the indictment listed the two types of property as follows:

(a) ... money and property in the form of tuition, room, board, fees, and other financial assistance provided to student-athletes on the basis of false certifications submitted to the student-athlete's school; and

(b) ... [the universities'] right to control the allocation of a limited number of athletic scholarships to student athletes who the universities considered to be eligible, under the rules and regulations adopted by the university, to compete and represent the school in intercollegiate football and to receive an athletic scholarship in that sport.

Id. (alterations in original).

208. Id. at 1444. 
schools suffered no economic loss. ${ }^{209}$ Walters argued that the schools would have paid out the same amount of money in scholarships regardless of the agents' plan - the scholarships would just be awarded to other athletes. He further explamed that the schools received what they paid for-football players. Moreover, because the agents' plan was not discovered until after the football season, the schools did not lose any revenues from the sport. 210

Walters's position was supported by dicta in United States $v$. Holzer. ${ }^{211}$ In Holzer, the Uinited States Court of Appeals for the Seventh Circuit reversed the mail fraud conviction of a state judge who accepted bribes because the conviction was based on the "intangible rights" doctrine invalidated by McNally. ${ }^{212}$ In deciding the case, the court commented:

A further complication in McNally was that the moneys the defendants had received were not bribes pure and simple. The state would have paid the commissions to some insurance agency, perhaps in the same amount-perhaps indeed to the same agency. The deprivation really was of an intangible right. 213

The Walters $I$ court acknowledged the logical appeal of the Holzer dicta, but declined to follow it. ${ }^{214}$ Instead, the court cited Carpenter for the rule that a victim need not suffer monetary loss under the mail fraud statute-it is enough if the victim lost the "right to control" or the "right to exclusive use" of the property. ${ }^{215}$

In Walters $I I$, Walters advanced a new argument regarding the $M C$ Nally requirement. ${ }^{216}$ Citing post-McNally decisions, Walters argued that the mail fraud statute only apphes where the "goal" of the scheme is to obtain money or property through fraud. ${ }^{217}$ After a careful review of

209. Id.

210. Id.

211. 840 F.2d 1343 (7th Cir. 1988).

212. The government attempted to recharacterize the fraud in Holzer to conform with McNally. Under a constructive trust theory, the prosecution argued that Holzer defrauded the state of money because Holzer accepted and retained the bribe money rather than passing it on to the state. This argument failed. Id. at 1348-49.

213. Id. at 1346-47.

214. 711 F. Supp. at 1446 n.8.

215. Id; see also id. at 1443-46. For discussion of Carpenter, see supra notes 189-90 and accompanying text.

216. Walters also raised the same argument advanced in Walters $I$-that the schools did not suffer an economic loss due to the agents' plan. The court rejected this argument for the same reasons as in Walters $I$. See Walters $I I, 775$ F. Supp. at 1176-79.

217. See id. at 1176. 
the cases, the court rejected Walters's interpretation. ${ }^{218}$ The court commented: "A more sensible interpretation of the statute would indicate that a scheme is devised 'for obtaining' money or property when the defendant knows that its success requires a specific fraudulent deprivation of money or property."219

Both Walters $I$ and Walters $I I$ recognized a second, separate type of property deprivation in addition to the scholarships-the "right to control" the distribution of a limited number of athletic scholarships. Initially, it appeared that Walters $I$ was not going to acknowledge this intangible right as a separate property right. 220 Yet the opinion stated that the "intangible property right to control disposition of property is protected by the mail fraud statute" under the Carpenter rationale.221 The court concluded that the universities' loss of the "right to control" distribution of the scholarships was the "gist" of the alleged fraudulent schenie. 222 The Walters II opinion also concluded that the universities' loss of the right to control the allocation of athletic scholarships due to the agents' scheme constituted a "brand new [property] deprivation."223

Both Walters $I$ and Walters $I I$ erroneously stretched Carpenter's holding that intangible property can be protected by the inail fraud statute. The intangible property interest recognized in Carpenter-the right to exclusive use of confidential business information-is much different than the nitangible right to control the allocation of athletic scholarships. The opinion in Carpenter noted that confidential business information, itself intangible property, has long been recognized as property. ${ }^{224}$ Furthermore, the opinion stressed that the confidential business information

218. See id. at 1177-79. The court distinguished the facts in Walters II from those in United States v. Regan, 713 F. Supp. 629 (S.D.N.Y. 1989), which had commented that "[i]t is not enough that the scheme be designed to deprive its victims of an intangible right for which money or property has been paid. The money or property deprivation must be a goal of the plot, not just an inadvertent consequence of it." Id. at 637. Regan involved a scheme to conceal a breach of contract; however, there was no evidence that defendants in Regan intended to breach the contract at the time they entered into it. According to the court, the distinguishing factor in Walters II was that the agents' scheme involved fraudulent misrepresentations. As a result, the schools were fraudulently induced to award scholarships in the first place. See Walters $I I, 775$ F. Supp. at 1178-79.

219. Walters $I I, 775$ F. Supp. at 1179.

220. To begin, the court noted that "[i]ntuitively, it is difficult to separate the tangible property of the scholarships from the intangible property right to control allocation or disposition of the scholarships." Walters $I, 711$ F. Supp. at 1445. The court then stated that this second type of property right (the "right to control") "is but one property right already encompassed by the bundle of property rights" accompanying the tangible scholarships, and that amateur competition rules limiting the number of scholarships a university can distribute "do[es] not create any additional property right." Id.

221. Id.

222. Id. at 1446.

223. Walters $I I, 775$ F. Supp. at 1179.

224. Carpenter, 484 U.S. at 26. 
constituted "news matter" and "stock in trade" that could be bought and sold like any other commodity. ${ }^{225}$ These attributes of property emphasized in Carpenter are notably lacking in the right to control the allocation of athletic scholarships.

The cases cited in Walters $I$ in support of applying Carpenter to the right to control the allocation of athletic scholarships can be distinguished. In United States $v$. Lytle, ${ }^{226}$ the government alleged a scheme by a bank einployee to defraud the bank of money by making loans in violation of the bank's lending rules. Lytle is consistent with Carpenter in that the bank was in the business of making loans, just as the Wall Street Journal was in the business of providing financial information to its readers. Unlike the situation in Carpenter, the universities are not in the business of awarding athletic scholarships; rather, they are in the business of providing education. United States v. Cooper ${ }^{227}$ and United States $v$. Thomas ${ }^{228}$ involved the fraudulent deprivation of wages secured through an einployer-employee relationship. Like confidential business information, an einployer's interest in wages has been recognized by the law as protectible property. ${ }^{229}$ The athletic scholarships do not fit into the category of wages. The scholarships represent an award to the athlete of tuition, room, board, books, and fees. In return, the athlete agrees to participate on the football team. Although the scholarships are contracts and have economic value, their value, unlike wages, is not based on the free-inarket systern. The NCAA rules support the position that athletic scholarships are not wages. ${ }^{230}$ Furthermore, in other situations, courts have rejected treating the umiversity and student-athlete as an employer-employee relationship. ${ }^{231}$ These distinctions undermine the argument that the universities have an economic imterest in scholarships equal to an employer's economic interest in wages. Whereas an employer's loss of the "right to control" affects his interests as a property

225. Id. (citing International News Serv. v. Associated Press, 248 U.S. 215, 236 (1918)).

226. 677 F. Supp. 1370 (N.D. Ill. 1988).

227. 677 F. Supp. 778 (D. Del. 1988).

228. 686 F. Supp. 1078 (M.D. Pa. 1988).

229. See, e.g., United States v. Granberry, 908 F.2d 278, 280 (8th Cir. 1990).

230. A basic policy of the NCAA is "to maintain intercollegiate athleties as an integral part of the educational program and the athlete as an integral part of the student body [to] retain a clear line of demarcation between college athletics and professional sports." NCAA CoNST. art. 2, § 2-(a), reprinted in NCAA MANUAL, supra note 8 , at 7-8.

231. Courts have held that student-athletes are not employees of the university for purposes of recovering workers' compensation. See, e.g., Rensing v. Indiana State Univ. Bd. of Trustees, 444 N.E.2d 1170 (Ind. 1983); see also Ray Yasser, Are Scholarship Athletes at Big-Time Programs Really University Employees-You Bet They Arel, 9 BLACK L.J. 65, $77-78$ (1984) (arguing that scholarship athletes at big-time universities should be considered employees of universities). 
holder, a university's loss of the "right to control" affects its interest only as a regulator.

Although no court has considered precisely the property issue presented in the sports agents' case, the situation is similar in many respects to mail fraud cases that involve the fraudulent issuance of licenses or permits in the regulatory context. The typical fact pattern in these cases involves an applicant who falsifies information on his or her application for a license or permit, just as the athletes in the Walters and Blooin case hed on the NCAA eligibility forms. ${ }^{232}$ Courts liave generally refused to extend the reach of the inail fraud statute to protect the property interest in the permit itself. ${ }^{233}$ These courts have reasoned that, although a governmental permit inay be property in the hands of the person who receives it, licensing authorities have no property interest in licenses or permits. ${ }^{234}$ One court that arrived at the contrary result based its opinion on the fact that the issuer was "in the "business" " of conveying such permits. ${ }^{235}$ Yet, as discussed above, ${ }^{236}$ this rationale does not exist for the universities' interest in athletic scholarships. ${ }^{237}$

The Seventh Circuit confronted such a licensing case prior to Walters I. In Toulabi v. United States, ${ }^{238}$ the court reversed the mail fraud conviction of a defendant charged witl furnishing prospective taxi drivers with the answers to a licensing test administered by the City of Chicago. The court held that Chicago's right to honest answers did not rise to the level of property. ${ }^{239}$ Toulabi is sound precedent that sliould have been followed by Walters $I$ and Walters II. The schools' purported right to control the allocation of athletic scholarships-or the riglit to loonest

232. See, e.g., United States v. Granberry, 908 F.2d 279 (8th Cir. 1990) (defendant applying for school bus permit concealed prior murder conviction).

233. See, e.g., id. at 280 (school bus operator permit); United States v. Kato, 878 F.2d 267, 26869 (9th Cir. 1989) (federal pilot licenses); United States v. Murphey, 836 F.2d 248, 254 (6th Cir.) (certificate of registration to conduct bingo games), cert. denied, 488 U.S. 924 (1988). But see United States v. Martinez, 905 F.2d 709, 713-15 (3d Cir. 1990) (license to practice medicine).

234. See Granberry, 908 F.2d at 280; Kato, 878 F.2d at 268-69; Murphey, 836 F.2d at 254.

235. United States v. Novod, 923 F.2d 970 (5th Cir. 1991). Novod involved the fraudulent attempt to obtain a permit to operate a waste dunupsite in New York. The court emphasized that its holding was based on the fact that the issuer of the permit (the New York State Department of Environmental Conservation) was, "in the "business" of conveying regulatory permits to responsible dumpsite operators." Id. at 975.

236. See supra text accompanying note 226.

237. Courts have been more willing to find mail fraud violations in the licensing cases based on the licensing authority's property interest in wages, rather than the permit itself. See, e.g., Granberry, 908 F.2d at 280 . Yet as previously explored, it is unlikely that an athlete's athletic scholarship constitutes a wage as typically understood in the enıloyer-employee context. See supra notes 227-31 and accompanying text.

238. 875 F.2d 122 (7th Cir. 1989).

239. See id. at 125 . 
answers-is not the type of intangible property interest recognized in Carpenter.

The Walters $I$ and Walters $I I$ analyses of the McNally objections indicate that the courts had to strain to fit the alleged property deprivation caused by the sports agents into the inail fraud statute. The opinions erroneously extended Carpenter to reach intangible property not before recognized at common law. Furthermore, the courts distinguished or ignored case law that suggested a contrary and better-reasoned approach. Judicial acquiescence in the latest expansion of the inail fraud statute is misgnided.

3. Errors in Mail Fraud Theory Revealed at Trial. The trial of Walters and Blooin exposed further errors with the government's theory of inail fraud. Under the "scheme to defraud" requirement, the government had to prove that Walters and Blooin had the specific intent to defraud the universities of a protectible property interest. ${ }^{240}$ The trial revealed that the agents lacked the specific intent to engage in a scheme to defraud the universities. Thus, the mail fraud charges should have been dismissed. 241

A ineaningful definition of the term "scheme to defraud" is lacking in Inail fraud jurisprudence. ${ }^{242}$ One oft-cited opinion defines "to defraud" broadly as "wronging one in his property rights by dishonest inethods or scheines" and "usually signif[ying] the deprivation of soniething of value by trick, deceit, chicane or overreaching."243 As the trial disclosed, Walters and Bloom did not specifically intend to "wrong" the universities by obtaining the scholarships. Nor did Walters or Bloom have the specific intent to deprive the universities of the economic value of the scholarships or the "right to control" the allocation of the scholarships. Walters and Bloom did intentionally act to sign college athletes to representation contacts in violation of the NCAA rules. They knew that their plan would have to be concealed froin the umiversities in order for the players to continue to play collegiate athletics. But knowledge of

240. Mail fraud is a specific intent crime. See 18 U.S.C. $§ 1341$ (1988); Walters $I I, 775$ F. Supp. at 1179 .

241. In Walters II, the court noted that "an indictment does not charge an offense under the mail fraud statute simply because the scheme 'results' in a deprivation of money or property." 775 F. Supp. at 1179. The court went on to hold the indictment sufficient on its face because it alleged specific intent. Although the court stated that "[d]efendant may be correct in his belief that the evidence likely to be advanced by the government at trial will be insufficient to support a guilty verdict," id. at 1180 , the court expressed no opimion on the subject. See id.

242. See Hurson, supra note 180, at 444; Rakoff, supra note 177, at 819; Mark C. Goodman, Note, The Federal Mail Fraud Statute: The Government's Colt 45 Renders Norby Walters and Lloyd Bloom Agents of Misfortune, 10 LoY. ENT. L.J. 315, 325-26 (1990).

243. Hammerschmidt v. United States, 265 U.S. 182, 188 (1924). 
concealinent is different than possessing the criminal intent to defraud soineone of his property. ${ }^{244}$

Abernethy v. State ${ }^{245}$ involved a fact situation similar to the Walters and Blooin scheine, but was decided under Alabama state law. Like Walters and Blooin, sports agent Jim Abernethy signed Auburn football star Kevin Porter to a representation contract before Porter's college eligibility expired. Abernethy also made payments to Porter. ${ }^{246}$ The state prosecuted Abernethy for the crime of seeking to influence the outcome of a sports contest. 247 Under one of its theories, the state argued that Abernetliy intended Porter to play while ineligible under NCAA rules. Because Porter's ineligibility created the possible result of loss through forfeiture, Abernethy was guilty of influencing the outcome of a sports event (even though Abernetly did not intend for Auburn to lose).248

A jury convicted Abernethy, but the conviction was reversed on appeal, where the court lield that "the State utterly and completely failed to prove that Abernethy tampered witl a sports contest with the criminal intent to influence its outcoine." 249 Noting that the state's theory was "unreasonable," the court stated: "Without the specific criminal intent of the statute, even an intentional violation of the N.C.A.A. rules resulting in a player being declared ineligible does not constitute the offense of tampering with a sports contest." 250 The Alabama sports bribery statute is narrower than the mail fraud statute; thus, the unreasonableness of the state's theory in attempting to fit Abernethy's conduct within the state statute is easier to see than in the Walters and Bloom case. ${ }^{251}$ But although the flexibility of the mail fraud statute is one of its greatest

244. The lack of criminal intent to defraud does not mean, of course, that the agents' scheme was ethical or beyond the scope of civil sanction. It only recognizes a basic principle in criminal lawthat unless a person acts with a specific criminal intent, that person should not be subject to the force and stigma of the crimiual läw. For adverse consequences of overextending the criminal law, see infra Part II(B). See also Goodinan, supra note 242, at 328-30 (arguing that Walters and Bloom did not have the specific intent to defraud the uriversities of property and that the student-athletes were the true fraud perpetrators).

245. 545 So. 2d 185 (Ala. Crim. App. 1988).

246. Id. at 186. As a result, Porter was deelared ineligible to compete for Auburn in the Sugar Bowl. Id.

247. See id. at 187 (charging Abernethy with violating ALA. CODE $§ 13 A-11-143$ (1975)).

248. See id. at 187-88.

249. Id. at 191.

250. Id. at 188.

251. The appellate court noted the trial judge's concerns about the case: " '[M]t's obvious to me that these statutes have been stretched to alinost the breaking poiut in order to try to einbrace the Defendant's conduct within the four corners of these statutes. And I have some doubts as to whether or not any one of these statutes apply [sic].' " Id. at 201 (quoting comments of trial judge from record). 
hallmarks, the statute is not so broad as to reach unethical schemes such as Walters and Bloom's that lack the specific intent to defraud.

Besides failing to prove that the agents acted with the requisite criminal intent, the trial revealed a fundamental flaw in the courts' analysis of the property interest even if the courts are correct in holding that the universities have a protectible property imterest im the scholarships, or a "right to control" the scholarships. ${ }^{252}$ In both Walters I and Walters $I$, the underlying assunption that allowed the courts to find a deprivation of the schools' property rights was the sanctity of the NCAA rules. Because adherence to the NCAA rules was instrumental to the government's theory of mail fraud, defendants sought to illustrate that the schools themselves often violated the NCAA rules. Evidence of widespread NCAA rule violations by the universities relates to the legal question of whether the schools were actually defrauded by the actions of Walters and Bloom. For if the schools had previously awarded scholarships to inehgible athletes and allowed them to compete, then those same schools could not legally complain that they were suddenly defrauded by the agents. ${ }^{253}$

To make their point about widespread NCAA rule violations, the defendants wanted to obtain and present evidence of all NCAA rule violations or investigations pertaining to the schools during the enrollinent period for student-athletes mentioned in the indictment. ${ }^{254}$ In a pre-trial evidentiary ruling, however, they were limited to obtaining documents relatimg to NCAA violations involving only the student-athletes named in the indictment. ${ }^{255}$ In rejectimg Bloom's request, the court acknowledged that the "unclean hands" theory was relevant to the defense, but only im mitigation. ${ }^{256}$ Despite this recognition, the court erroneously restricted the defendants' ability to assert their "unclean hands" defense by

252. See supra notes 206-39 and accompanying text.

253. This argument is similar to the "unclean hands" theory found in other areas of the law. See, e.g., RESTATEMENT (SECOND) OF TORTS $\$ 940$ (1979) (reciting rule that related misconduct by plaintiff is one factor to be considered in determining the appropriateness of injunctive relief).

254. Specifically, Bloom sent a subpoena to schools requesting

all documents relating in any way to any inquiry, allegation, complaint or information received by the association relating to the representation of any student-athlete by an agent or other representative, allegedly in violation of any Big Ten or NCAA rule, regulation, policy, or requirement, during the enrollment period for student-athletes mentioned in the indictinent.

United States v. Walters, No. 88 CR 709, 1989 WL 20849, at *1 (N.D. Ill. Feb 13, 1989).

255. See id. at $* 2$.

256. The court stated: "Evidence of a university's failure to revoke other student-athletes' scholarships may be relevant in mitigation but it is not relevant to the issue whether the schools were defrauded.... Speculation that the university would have ignored the correct information is irrelevant." Id. 
limiting the scope of discovery. Because the universities' "property interest" as accepted by the courts rested on the assumption that the schools always follow the NCAA rules, the defendants should have been able to present evidence and cross-examine witnesses to challenge the validity of that assumption.

It is important to note that the defense strategy was successful with regard to those schools evidenced to have committed the most NCAA rule violations, even though the defense was limited to presenting evidence of violations involving ouly the student-athletes who testified. The jury found that Walters and Bloom were not guilty of defrauding two universities because of those schools' questionable enforcement of NCAA eligibility rules. ${ }^{257}$ This result suggests that if defendants had been allowed to present evidence of NCAA rule violations or investigations regarding other student-athletes (assuming that the schools had such evidence), then the agents would have been found not guilty of committing inail fraud at all.

The government's theory of mail fraud may be tenable under a very broad reading of the statute. Yet, as Walters $I$ and Walters II illustrate, the statute must be stretched to absurd limits. Such a broad reading is unsound for legal reasons. Furthernore, the expansion of the niail fraud statute should be rejected based on policy reasons; this will be discussed in the following section.

\section{B. Policy Reasons Against Extending the Mail Fraud Statute}

Even if the government's new theory of mail fraud is acceptable under a generous reading of the mail fraud statute, the trial of Walters and Bloom revealed policy reasons that weigh overwhelmingly against such an expansive interpretation. Many of these policy reasons parallel the concerns raised in association with "overcriminalization." The overcriminalization debate ${ }^{258}$ concerns the proper limit at which the law can legitimately pumish beliavior, without crossing the point where society feels it is " 'not the law's busmess." "259 Increased disrespect for the law, discriminatory enforcement, and waste of judicial resources are problems

257. The jury found the agents guilty of defrauding the University of Michigan and Purdue University. For a criticism of the jury's verdict nil hight of ni-house rule violations at universities, see Steve Fiffer, Agents' Trial: Why Bother?, N.Y. TIMEs, Apr. 16, 1989, § 8, at 5.

258. For background on the overcriminalization debate, see John M. Junker, Criminalization and Criminogenesis, 19 UCLA L. REv. 697 (1972); Sanford H. Kadish, The Crisis of Overcriminalization, ANNALS, Nov. 1967, at 157; Sanford H. Kadish, More on Overcriminalization: $A$ Reply to Professor Junker, 19 UCLA L. REv. 719 (1972).

259. Junker, supra note 258, at 697 (quoting Home OFFICE, SCOTTISH HOME DePartmeNt, REPORT OF THE COMM. ON HOMOSEXUAL OFFENCES AND PROSTITUTION $§ 61$ (1957) (commonly known as the "Wolfenden Report")). 
associated with overcriminalization. ${ }^{260}$ These problems are evident from the sports agents' trial.

1. Increased Disrespect for the Law. Increased disrespect for the law as a result of the sports agents' trial manifested itself in at least three ways. To begin, even the jury admitted that they had to stretch the law to reach Walters and Blooin on the inail fraud charges. When questioned by reporters after the trial, the forewoman of the jury admitted that the jury had to do "soine stretching"261 to reach their verdict. In addition to stretching the law, the jury felt that "there were no innocent bystanders."262 The jury's feelings were shared by many people. The convictions of Walters and Blooin for mail fraud produced a strong outcry from many seginents of the public in liglit of the other abuses in college sports. ${ }^{263}$ Fimally, soine people coinplained that the government should liave focused its energy and resources on other crimes. As one reporter who covered the trial commented:

I think you could take a baseball and throw it out this window in any direction and have a pretty good chance of hitting a dope dealer on the head. It was a colossal waste of the Government's time and money to go after Walters and Bloom when there wasn't even a crime committed. ${ }^{264}$

There are at least two reasons for the negative reactions to the convictions of Walters and Blooin that lead to public disrespect for the law. First, if Walters's and Blooin's alleged connections to organized crine are excluded, there are many people who think that the agents' actions of signing college athletes to representation contracts and giving them money is not wrong. ${ }^{265}$ Sucli actions are not normatively wrong-they

260. See Coffee, Criminal Status of Confidential Information, supra note 180, at 147-52 (discussing the problems of overcriminalization in light of Carpenter); Junker, supra note 258, at 699-714 (outlining the problems associated with overcriminalization and offering a rebuttal).

261. Fiffer, supra note 257, at 5 .

262. Ira Berkow, Was a Crime Really Committed?, N.Y. TiMEs, Apr. 17, 1989, at C5.

263. See id. (arguing that the problem is not inerely Walters and Bloom, but a "corruption of values" by overemplasizing sports and underemplrasizing education); Fiffer, Agents' Trial, supra note 257, at 5 (stating that the jury was overwhelmed by corruption in college sports); Telander, $A$ Question of Fairness, supra note 149, at 114 (arguing that Walters and Blooin are "convenient fall guys whom the sanctimonious chiefs of niajor college sports can castigate while ignoring the real ills in their realm"); Letter to the Sports Editor, It Was the Business of College Sports on Trial, L.A. TIMES, Apr. 22, 1989, § III, at 3 (claiming that the Walters and Bloom trial was "exploiting the deeper liypocrisy of college sports").

264. Fiffer, supra note 257, at 5.

265. Sociologist Allen L. Sack of the Umiversity of New Haven surveyed professional football players about their experience witl payments as college atliletes. Of the 1182 current or former NFL players who responded, $31 \%$ stated that they accepted payments while in college in violation of NCAA rules and $48 \%$ responded that they knew of players who accepted payinents. Moreover, more than half of the respondents did not think that there was anything wrong with accepting 
are only wrong because the NCAA eligibility rules do not allow them. Yet as the trial illustrated, there are many problems with the NCAA rules themselves. ${ }^{266}$ The NCAA has attracted as much criticism as bad sports agents. 267

It is axiomatic that the criminal law is supposed to discourage behavior that society believes is harmful. Through criminal laws, the public can define what conduct is criminal, and can prescribe the proper punishment for that conduct. ${ }^{268}$ Often, there is a fine line between what constitutes a criminal act that warrants criminal prosecution and what constitutes an immoral act that may not warrant a criminal sanction. Not every unethical or immoral act falls withm the realm of the criminal law. ${ }^{269}$ Although sports agents who give college athletes money and gifts in violation of NCAA rules may behave unethically, it is a different inatter to label thein "criminals." Transgressions of criminal laws carry a distinct stigma. When the reach of the criminal law is extended to behavior that inany consider to be acceptable, it loses its special stigma and "invites the public to become cynical about the law's premises."270

The second source of criticisin is that Walters and Bloom were not given notice that their actions were criminal. Because of the severe sanctions that can be brought to bear on a "criminal," the criminal justice system contains basic premises and procedures to ensure that the power of the criminal law is not abused. One general premise, based on the notion of fair play, is that there must be soine warning to the public that

money while in college. Eighty percent believed that the college players should be better compensated than currently provided by the NCAA. Douglas Lederman, 1 in 3 Pro Football Players in Survey Took Payments While in College, ChroN. Higher Educ., Nov. 29, 1989, at A43; see also Jill Lieber, Extra Points, SPORTS IllustraTED, Dec. 9, 1985, at 74 (noting that a survey of 224 NFL players revealed that 129 were in favor of paying college athletes).

266. See supra Part I(D).

267. See generally SPERBER, supra note 2, at 307-42; Telander, Something Must Be Done, supra note 82, at 92 (explaining his visceral fcelings about the NCAA: "I hate it. I see the NCAA as a bunch of know-nothing, self-righteous stuffed suits who are willing to do just enough to keep the organization running."); Yasser, supra note 231, at 77-78 (arguing that scholarship athletes are einployees for workers' compensation and that such a recognition by the courts will lead to healthy reform of the college sports system); Lee Goldman, Note, Sports and Antitrust: Should College Students Be Paid to Play?, 65 Notre DAME L. Rev. 206 (1990) (arguing that they should); Adam Hoeflich, Note, The Taxation of Athletic Scholarships: A Problem of Consistency, 1991 U. ILL. L. REV. 581, 594 (student-athletes are highly exploited, underpaid professionals).

268. See generally WAYNe R. LAFAVE \& AUSTIN W. ScoTt, JR., CRIMINaL Law §§ 1.2-.6 (2d ed. 1986) (providing background on general purposes and theories of criminal law and punishment). 269. See id. $\S 1.2(f)$ (citing omissions to act as, although often times immoral, generally not treated as criminal).

270. Coffee, Criminal Status of Confidential Information, supra note 180, at 149. 
defines what conduct is criminal and how the act will be punished.271 Thus, it is important that there be in place some discernible limit to the reach of the inail fraud statute; otherwise, its use will often cross the constitutional line. 272

Of course, Walters and Blooin were not synipathetic defendants. Given the testimony of several players that Walters and Bloon1 threatened them with physical harm, one could argue that the respect for the law may have been diminished if the agents were not convicted.273 After the trial, the prosecution admitted that the extortion claims and organized crime connections were at the heart of the case. ${ }^{274}$ Thus the prosecutor could have used other laws to seek convictions of Walters and Bloom without having to stretch the mail fraud statute to the point of inviting public criticisin and scorn. ${ }^{275}$

2. Discriminatory Enforcement. The Walters and Bloom trial revealed a second problem with the government's new mail fraud theorydiscriminatory enforcement. One of the dangers of an expansive interpretation of the mail fraud statute is that it will be enforced not uniformly, but based on prejudices and passions of the day. Agents, who

271. Vague laws that do not give sufficient notice of proscribed behavior are unconstitutional under the Due Process Clauses of the Fifth and Fourteenth Amendments. See, e.g., Grayned v. City of Rockford, 408 U.S. 104 (1972):

Vague laws offend several important values. First, because we assume that man is free to steer between lawful and unlawful conduct, we insist that laws give the person of ordinary intelligence a reasonable opportunity to know what is prohibited, so that he may act accordingly. Vague laws inay trap the imnocent by not providing fair waming. Second, if arbitrary and discriminatory enforcement is to be prevented, laws must provide explicit standards for those who apply them. A vague law impermissibly delegates basic policy inatters to policemen, judges, and juries for resolution on an ad hoc and subjective basis, with the attendant dangers of arbitrary and discriminatory apphication.

Id. at 108-09 (footnotes omitted).

272. Because of these concerns, defendants cliallenged the mail fraud cliarge on due process grounds. In Walters $I$ the court denied the due process cliallenge. 711 F. Supp. 1435, 1446-47 (N.D. Ill. 1989). The court ruled that the statute was sufficiently clear in that (1) the general definition of fraud fits defendants' acts, and (2) the attempts by defendants to conceal their plan is evidence that defendants knew that their sclieme was wrong. Id.

273. In criticizing the expansion of the mail fraud statute into the area of white collar crime in the 1980s, Professor Coffee raised this same point by noting that the American public wanted Ivan Boesky to go to jail. See Coffee, Criminal Status of Confidential Information, supra note 180, at 12124.

274. See Steve Fiffer, Prosecutor's View of Agents, N.Y. TIMES, Apr. 23, 1989, § 8, at 4 ("The lieart of this case was the organized-crime aspect.").

275. The agents could have been proseeuted under other federal laws. See, e.g., 18 U.S.C. $\S 1951$ (1988) (crimmalizing interference witl cominerce by threats or violence). A variety of state criminal laws may have been applicable. See, e.g., KY. REv. STAT. ANN. § 514.080 (Michie/BobbsMerrill 1991) (tlreft by extortion). Civil remedies also existed for the victims of the alleged fraudulent scheme. See generally Woods \& Mills, supra note 47 (arguing that universities have an action for the tort of intentional interference with contractual relations against bad sports agents). 
have been described as "vipers, parasites, charlatans, vultures, bloodsuckers, and leeches,"276 will face an increased risk of prosecution because of their status. Based on the trial, it is fair to assume that the government will use the inail fraud statute to prosecute sports agents only. Walters and Bloom, as sports agents with alleged connections to organized crime, were prime targets for the expansive use of the mail fraud statute.277

Under the government's new theory, many actors in addition to the agents are brought within the realm of criminal activity. Anyone who knowimgly causes a college player to violate a NCAA rule could be prosecuted for mail fraud because the college player inust complete the required eligibility form, which is mailed to the athletic conferences.278 Scholarship athletes who knowingly violate any NCAA rule will techincally fall within the scope of the mail fraud statute. ${ }^{279}$ Indeed, the players who accepted money from Walters and Bloom were threatened with prosecution for mail fraud. ${ }^{280}$ It was clear, however, that the government was not interested in prosecutimg the players. The government not only offered the players favorable pre-trial diversion programs, ${ }^{281}$ but also failed to force all of the players to comply with the program's requirements. 282

Under the government's theory of mail fraud, many boosters would qualify as criminals for giving favors to athletes in violation of NCAA rules. ${ }^{283}$ Coaches or other university officials could also coine within the

276. Ehrhardt \& Rodgers, supra note 4, at 634.

277. The mail fraud statute has been used against other agents as well. Four sports agents were indicted for mail fraud resulting from an investigation into alleged abuses at the Umiversity of Florida that included charges of assault, drug use, fraud, gambling, and illegal payoffs. The investigation also led to the resignation of Florida's football coach, Galen Hall, and basketball coach, Norm Sloan, amid charges of mail fraud and perjury. Elliott Teaford, Troubled Gators Just Happy to Be Playing Football, L.A. TIMES, Dec. 29, 1989, at C9.

278. See supra text accompanying notes 174, 175-76.

279. Following the government's theory to its logical end, whenever a scholarship athlete completes a false NCAA eligibility statement and the school mails the statement to the NCAA, the player's actions fall within the mail fraud statute. Assuming the player has the intent to defraud, the player has schemed to defraud the university out of its property interest in the scholarship, and the player has caused a mailing in furtherance of the scheme. Thus, a scholarship athlete who works 10 hours a week at the local pizza restaurant (to earn spending money that the scholarship does not provide) in violation of NCAA rules is in jeopardy of being charged with mail fraud.

280. See supra note 69 and accompanying text; see also Goodman, supra note 242, at 329-30 (arguing that the true perpetrators of mail fraud under a technical reading of the mail fraud statute were the student-athletes).

281. See supra text accompanying notes $69-70$.

282. See Gorman, supra note 106 , at $\mathrm{Cl}, \mathrm{C} 6$.

283. Unlike alumni, boosters have no affiliation with the school other than to support its teams. Boosters are a major source of NCAA rule violations. Boosters have been known to give money to athletes, to provide cars and other gifts, and to secure sumner employment for the athletes. See 
ambit of the mail fraud statute for lending money to a student-athlete or otherwise violating an NCAA rule. As with the players, however, it is unlikely that the mail fraud statute will be used agamst boosters, coaches, or other university officials.

3. Waste of Judicial Resources. Perhaps the most important policy reason for the rejection of the government's theory of mail fraud is that the mail fraud statute is too blunt an instrument to use to address the myriad problems im college sports. As such, prosecuting sports agents under the mail fraud statute is a poor allocation of scarce judicial resources. Furthermore, rehiance on the mail fraud statute may slow reformers from addressing the underlying problems im college sports that create the climate for corruption and abuse. As the Walters and Blooin trial disclosed, the probleins of college sports cannot be blained solely on bad sports agents. ${ }^{284}$ Although Walters and Bloom were arguably unethical and unscrupulous, other culpable actors were involved. Student-athletes participated in the plan, 285 and many umiversities contributed to the corrupt climate. ${ }^{286}$

The trial revealed that the NCAA rules are the major source of the problems in college sports. ${ }^{287}$ Because of the problems caused by the NCAA rules, the resort to the mail fraud statute is a "quick-fix" that does not address the systemic problems or other culpable actors in college sports. Until the NCAA rules themselves are reformed, the agents, student-athletes, and schools will continue to violate the NCAA rules, despite the mail fraud statute.

Unlike other areas of the criminal law where attacks on the sources of the problems may prove too costly, 288 changes to the NCAA rules will not require a huge capital outlay. Furthermore, reform can improve the college sports system without dramatically altering its nature. The economic pressure that has built up between professional sports and college sports needs to be relieved. The NCAA rules need to reflect the best interests of the student-athletes. The obligation of the schools to provide

\footnotetext{
generally SPERBER, supra note 2, at 70-79 (describing powerful role of boosters in college sports and noting that almost half of the penalties due to NCAA rule violations involve boosters).

284. See supra Part I.

285. See supra Part $\mathrm{I}(\mathrm{B})$.

286. See supra Part $\mathrm{I}(\mathrm{C})$.

287. See supra Part I(D).

288. Drug abuse is one area where the cost of attacking the root causes of the problem outweigh the cost of law enforcement and criminal proceedings. See Martin L. Haines, Crime and the Courts: A False Counterpoise, N.J. L.J., Dec. 27, 1990, at 14 (stating that the causes of drug abuse include lack of education, housing, einployinent, and healthcare; breakdown of the family; and poverty).
} 
meaningful education to student-athletes must be reinforced with actions, not just words. The government should use its prosecutorial discretion to refuse to prosecute sports agents for mail fraud. This decision will send a clear signal to the NCAA to reform its program. Such a reform will conserve scarce judicial resources by minimizing the problems in college sports at their source. In the long run, this course of action will do more to solve the problem of the bad sports agent than the mail fraud statute.

\section{CONCLUSION}

The trial of Walters and Bloom told the story of two unethical sports agents who violated the NCAA rules with impunity, driven by the desire to secure a position in the lucrative professional sports market. The trial also told the story of other unethical actors-student-athletes who take money from agents with no intention of repayment, colleges who are more concerned about economic gains for the athletic department than providing real educations to student-athletes, and the NCAA, whose unreasonable rules have created the abuse-prone environment of college sports. During the trial, it was often difficult to separate the good actors from the bad actors.

In the end, the trial of Walters and Blooni revealed several lessons. First, the government's new theory of mail fraud stretches the statute to absurd limits and should be rejected on legal and pohicy grounds. Perhaps the primary danger of such an overbroad use of the mail fraud statute is that it blurs the distinctions between the separate branches of power in the government. Prosecutors and judges begin to reseinble legislators. In this respect, the attempt to stretch the mail fraud statute in the Walters and Bloom situation is a clear signal that specific legislation is needed to address the problems in regulating sports agents. Some commentators have called for federal regulation because of the national scope of the sports imdustry. ${ }^{289}$ Many states have enacted sports agent legislation in the wake of the Walters and Blooin trial. The statutes generally strengthen the rules of the NCAA by adding the force of criminal sanctions. ${ }^{290}$

289. See Sobel, supra note 10, at 785-86; Jeffrey P. Crandall, Comment, The Agent-Athlete Relationship in Professional and Amateur Sports: The Inherent Potential for Abuse and the Need for Regulation, 30 BuFF. L. Rev. 815, 841 (1981); Dunn, supra note 10, at 1074-78.

290. See, e.g., FLA. STAT. ANN. $\$ 468.454$ (West 1991). Under this provision, both agent and student-athlete have the duty to inform the school that the player has entered into a representation contract. If the agent fails to notify the school, the agent may be found guilty of a third-degree felony. If the student-athlete fails to notify, he is subject to first-degree misdemeanor charges. See also Jan Stiglitz, NCAA-Based Agent Regulation: Who Are We Protecting?, 69 N. DAK. L. REV. 215, 219-26 (1991) (examining new state statutes and noting that 20 states have some form of NCAA- 
Yet this trend to adopt criminal sanctions based on NCAA regulations must be questioned due to the second lesson of the trial-that the NCAA rules themselves need to be reformed. Legislative action, whether at the federal or state level, must address the systemic problems posed by the NCAA rules. Unless the NCAA rules are reformed, there will remain a heightened potential for abuse and corruption in college athletics despite the mail fraud statute or other legislative action.

Most important, the trial of Walters and Bloom reminds us that culpability should be measured within a context. Because Walters and Bloom operated within a world of many culpable actors, their actions should not have been made criminal through the use of the mail fraud statute. However, if the NCAA and the schools reform their prograins to be more responsive to the best interests of student-athletes, the relative culpability of the bad sports agent would rise. Thus, a firmer ground would exist for targeting the bad sports agent with criminal sanctions. 